\title{
The role of peptides in bone healing and regeneration: a systematic review
}

\author{
Ippokratis Pountos ${ }^{1}$, Michalis Panteli ${ }^{1}$, Anastasios Lampropoulos ${ }^{1}$, Elena Jones ${ }^{2}$, Giorgio Maria Calori ${ }^{3}$ \\ and Peter V. Giannoudis ${ }^{1,4^{*}}$
}

\begin{abstract}
Background: Bone tissue engineering and the research surrounding peptides has expanded significantly over the last few decades. Several peptides have been shown to support and stimulate the bone healing response and have been proposed as therapeutic vehicles for clinical use. The aim of this comprehensive review is to present the clinical and experimental studies analysing the potential role of peptides for bone healing and bone regeneration.

Methods: A systematic review according to PRISMA guidelines was conducted. Articles presenting peptides capable of exerting an upregulatory effect on osteoprogenitor cells and bone healing were included in the study.

Results: Based on the available literature, a significant amount of experimental in vitro and in vivo evidence exists. Several peptides were found to upregulate the bone healing response in experimental models and could act as potential candidates for future clinical applications. However, from the available peptides that reached the level of clinical trials, the presented results are limited.

Conclusion: Further research is desirable to shed more light into the processes governing the osteoprogenitor cellular responses. With further advances in the field of biomimetic materials and scaffolds, new treatment

modalities for bone repair will emerge.
\end{abstract}

Keywords: Peptides, Mesenchymal stem cells, Bone healing, Growth factors

\section{Background}

After a traumatic insult to the bone, the musculoskeletal system mounts both local and systemic reactions facilitating the prompt restoration of the continuity of bone and normal function. Unfortunately, this process is not always successful. Approximately $5 \%$ to $10 \%$ of the fractures occurring are associated with impaired healing, including delayed union or non-union [1-5]. Fracture non-union often results in devastating outcomes for the patient and the surgeon $[2,5,6]$, requiring a complex, long-lasting and expensive treatment, and a variable degree of morbidity is often a common finding $[2,7,8]$.

In established non-unions and bone defects, bone grafting is a common procedure. It is estimated that 1.5 million bone grafting procedures are performed annually

\footnotetext{
* Correspondence: pgiannoudi@aol.com

'Department of Trauma \& Orthopaedics, School of Medicine, University of Leeds, Leeds, UK

${ }^{4} \mathrm{NIHR}$ Leeds Biomedical Research Unit, Chapel Allerton Hospital, LS7 4SA

Leeds, West Yorkshire, Leeds, UK

Full list of author information is available at the end of the article
}

in the USA and this figure is rapidly increasing due to population ageing [2, 7, 9-13]. The intense research in this field seen over the last few decades, has resulted in the discovery of several proteins that can upregulate the bone healing response [14, 15]. Bone morphogenetic proteins (BMPs) are the most representative example, which have been granted US Food and Drug Administration (FDA) approval for clinical applications in recalcitrant long bone non-unions, lumbar fusion and open tibial shaft fractures [16-18]. Several other proteins have shown to upregulate the osteogenic bone healing process [19-22]. However, the high cost derived from the purification techniques and the high doses required due to the instability of these molecules in vivo are the two most significant points of concern [23]. Recombinant DNA technologies have simplified the production of these molecules and the discovery of a variety of osteogenic peptides has emerged [24].

The terms protein, polypeptide, oligopeptide and peptide are rather ambiguous and overlapping in their meaning 
[25]. Proteins usually refer to denote an entire biological molecule in a stable conformation, while peptides refer to short amino acid oligomers most commonly lacking a stable 3-dimensional structure. In general, they exert their effect through binding to specific high-affinity receptors on the respective target cell receptors [25].

To date, a number of peptides have been engineered to upregulate the osteogenic response. Although BMPderived peptides are the most studied, other peptides also exist. The aim of this study is to identify the currently existing osteogenic peptides, other than those derived from BMPs and to investigate their impact in the upregulation of bone healing and bone regeneration.

\section{Methods}

This review was conducted in accordance to the PRISMA guidelines [26]. Publications from January 1980 to date were included.

\section{Eligibility and exclusion criteria}

Studies selected were original articles publishing results on the effect of different peptides on osteoblasts and osteoprogenitor cells as well as in vivo studies on bone healing. All studies that did not fulfil all eligibility criteria were excluded from further analysis. Exclusion criteria included manuscripts in languages other than English and those with incomplete documentation. Also, peptides related to BMPs or those related to cells types or conditions distant to bone healing or bone cells were excluded from the selection process as these were out of the scope of the manuscript.

\section{Information sources}

Studies were identified by searching PubMed Medline, Ovid Medline, Embase, Scopus, Google Scholar, and the Cochrane Library to retrieve all available relevant articles. The terms used for the search included combinations of primary keywords including 'peptide', 'sequence', and 'motif' with secondary keywords including 'bone, 'osteoblast', 'bone healing, 'mesenchymal, 'fracture, 'non-union, 'osteoprogenitor cells', 'stem cells, 'growth factor', and 'extracellular matrix'. The identified articles and their bibliographies, including any relevant reviews, were manually searched for additional potential eligible studies.

\section{Study selection}

Two of the authors (IP, MP) performed the eligibility assessment in an independent, unblinded and standardised manner. Most citations were excluded on the basis of information provided by their respective title or abstract. In any other case, the complete manuscript was obtained, scrutinised by the two reviewers and included if fulfilling the eligibility criteria.

\section{Results}

Out of 6017 papers that were initially identified, 197 met the inclusion criteria (Fig. 1) [27-223]. These studies are presented below.

\section{Parathyroid hormone-related peptides \\ Parathyroid hormone 1-34 peptide (Teriparatide)}

Parathyroid hormone (PTH) is an 84-amino acid, naturally occurring protein that plays a major regulatory role in mammalian mineral ion homeostasis. The peptide derived from its 34 amino acid domain has similar activity to the full length protein [224]. $\mathrm{PTH}_{1-34}$ is one of the earliest artificially synthesized amino acid fragments that was granted approval for the prevention and treatment of osteoporosis. Among its several functions, $\mathrm{PTH}_{1-34}$ stimulates osteoblast proliferation, differentiation and prevents their apoptosis (Fig. 2) [51].

Synthetic matrix made of polyethylene-glycol containing $\mathrm{PTH}_{1-34}$ significantly stimulated in situ bone augmentation in rabbits [29]. Evidence from animal models shows that daily subcutaneous injections of $\mathrm{PTH}_{1-34}$ significantly increased the bone mineral content and density as well as the total osseous tissue volume, torsional strength and stiffness [27, 30]. Additionally, accelerated callus mineralization, increased bone density at the fracture site, and better mechanical properties of the united bone have been reported [27, 31, 32, 47-51].

To date, several case reports have indicated that teriparatide could facilitate the healing of sternal non-union [34], stress fractures [35], atrophic humeral shaft non-union [36], femoral non-union [37, 41, 42, 47, 225], hip fractures [40], delayed unions [38, 43, 44], periprosthetic fractures [45], and sacral and pubic insufficiency fractures [39].

In a prospective randomized double-blind study, Aspenberg et al. [28] analysed the effect of daily

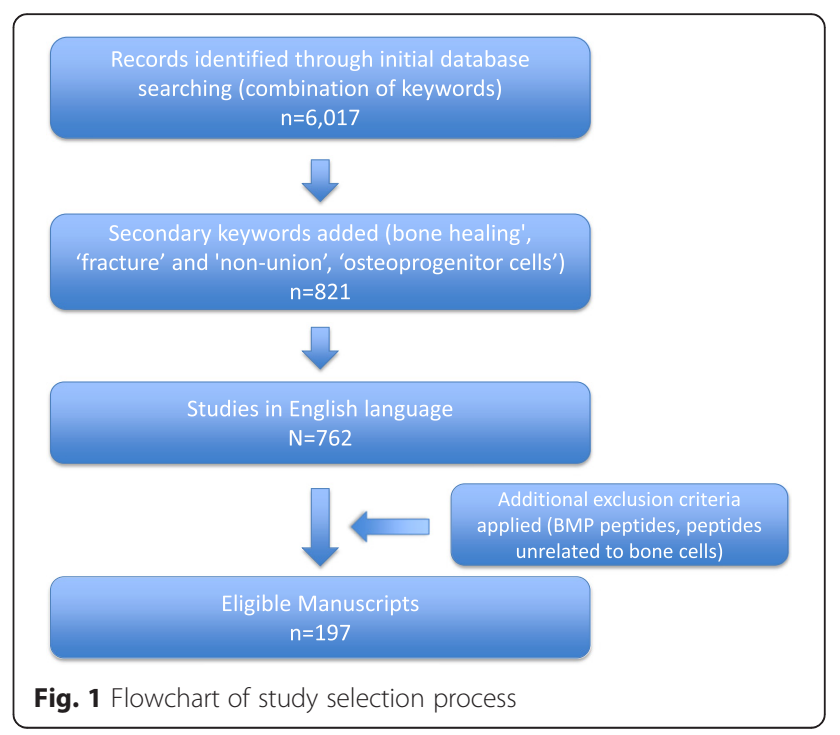




\section{Potential pathways and effect of peptides on the osteoblastic cell lines}

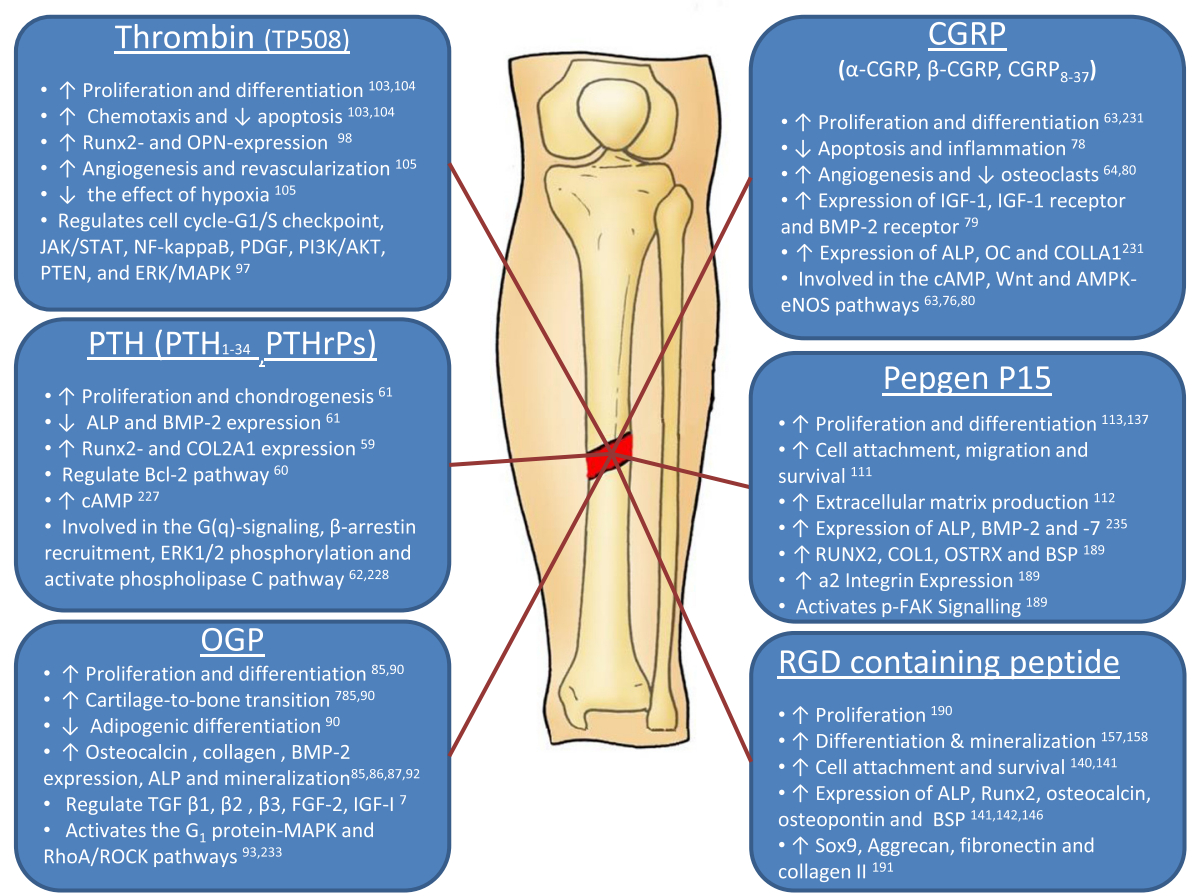

Fig. 2 Potential pathways and effect of peptides on the osteoblastic cell lines

injections of 20 and $40 \mu \mathrm{g}$ of recombinant teriparatide against placebo in post-menopausal women who sustained a distal radial fracture. Although they reported no significant difference between the teriparatide $40 \mu \mathrm{g}$ versus placebo groups, they reported a shorter time to healing between the teriparatide $20 \mu \mathrm{g}$ group and placebo $(P=0.006)$. In a post hoc subgroup analysis by the same group, blinded qualitative scoring of the calluses at 5 weeks suggested that patients who received $\mathrm{PTH}_{1-34}$ had a more 'rich' callus formation [33].

\section{Parathyroid hormone-related protein}

Human parathyroid hormone-related protein (PTHrP) consists of 139-175 amino acids and is a key regulator of cell growth, differentiation, and development of the foetal skeleton [59-62, 226-228]. Endogenous PTHrP plays an important role in fracture healing as demonstrated in an PTHrP haplo-insufficiency model where reduced cartilaginous and bony callus formation was noted together with reduced endochondral and osteoblastic bone formation [229]. However, a PTHrP $\mathrm{PH}_{1-34}$ maintains a less pronounced anabolic effect to the bone and osteoblasts possibly due its higher clearance rate $[52,53]$. To overcome this weakness, several analogues have been developed to date [54-57].

PTHrP ${ }_{1-36}$ exerts an anabolic action to bone, including enhanced bone histological features and raised osteoblast differentiation markers in the long bones and plasma in mice [57]. Cavitary bone defects treated with $\mathrm{PTHrP}_{107-111}$ improve local bone induction in a rabbit femoral cavity defect model [58]. A C-terminally substituted analogue of $\mathrm{PTHrP}_{1-34}$, the RS-66271, was found to increase trabecular and cortical bone in ovarectomized osteopenic rats [54]. In an impaired bone healing animal model, daily injections of RS-66271 resulted in a larger callus area, greater stiffness and torque when compared with controls [56]. A similar analogue of PTHrP, the RS-50303, was found to enhance fracture healing in a rat femoral osteotomy model [55].

\section{Calcitonin gene-related peptide}

Calcitonin gene-related peptides (CGRP) are found in two forms, $\alpha$ and $\beta$. $\alpha$-CGRP derives from the Calca gene and consists of 37 amino acids [230]. It has a $20 \%$ homology with calcitonin. In contrast, $\beta$-CGRP derives from a separate gene, termed Calcb, which is located in close proximity to Calca. In bone, CGRP is found in the sensory nerve endings in periosteum, bone marrow and metaphysis [66]. Among its several functions, CGRP has been found to stimulate the proliferation and differentiation, and to reduce the apoptosis of osteoprogenitor cells $[63,64,75,79,231]$. CGRP levels increase in patients with fractures, and it has been postulated that this plays an important role during the inflammatory stage of bone healing and overall during damaged tissue repair $[72,80]$. Transgenic mice engineered to overexpress CGRP have 
been found to have high trabecular bone density and bone volume [65], also associated with an increase in bone formation rate. On the contrary, $\alpha$-CGRP null mice developed osteopenia caused by a reduced bone formation rate [69]. CGRP was also found to stimulate the production of osteogenic molecules like IGF-I and BMP-2 [76-78].

Despite the abovementioned experimental evidence, limited in vivo studies have explored the potential supplementary effect of CGRP on bone healing. The literature suggests that, during fracture healing, the systemic levels of CGRP increase [72]. Fracture evokes an intense local in-growth of new nerve fibres containing CGRP thus possibly playing a role in the bone healing process [71]. When the bony innervation is disrupted locally, this results in an insufficient fracture callus [73]. Furthermore, Song et al. [70] speculated that the increased levels of CGRP secondary to traumatic brain injury may have led to the enhancement of fracture healing seen in this patient group. In an experimental model of induced fatigue bone damage, administration of CGRP or CGRP(8-37) increased reparative bone formation [74].

\section{Osteogenic growth peptide (OGP)}

OGP is a naturally occurring, highly conserved, 14amino acid, $\mathrm{H} 4$ histone-related peptide [81], abundant in human and mammalian blood as well as in culture media of osteoblasts and fibroblasts [81, 82]. Following its dissociation from the $\mathrm{a}_{2}$-macroglobulin, the peptide is proteolytically cleaved to generate a C-terminal pentapeptide, which activates an intracellular Gi-protein-MAP kinase signalling pathway [232, 233].

OGP was found to exert an anabolic effect on bone cells, resulting in an increase of bone formation and overall bone mass $[81,83]$. In vitro studies have shown that OGP can regulate osteoprogenitor cell proliferation, differentiation, alkaline phosphatase activity, osteocalcin secretion, collagen and matrix mineralization [85-87, 92]. In vivo OGP was found to regulate TGF-b1,b2,b3, FGF-2, IGF-I and aggrecan [85]. Further, transgenic mice overexpressing OGP have significantly increased peak bony mass [91].

Experimental fracture healing models have shown that OGP can serve as a potential candidate in enhancing the bone healing response (Table 1) [83-85, 88, 89]. Systemic administration of OGP accelerated bony union with enhanced bridging across the fracture gap, higher volume of callus and newly formed bone [85, 89]. Shuqiang et al. [84] treated 1.5-cm segmental defects in rabbits with an OGP incorporated in a PLGA scaffold. Their results showed a higher bony volume and acceleration of bone healing response.

\section{Thrombin Peptide 508 (Chrysalin)}

Thrombin peptide 508 (TP508), also known as Chrysalin, is a 23-amino acid synthetic peptide that represents the non-proteolytic receptor binding domain of thrombin. TP508 mimics some specific attributes of the thrombin, without the undesirable blood clotting effects. TP508 was found to enhance the proliferation and differentiation of and induces chemotaxis in human osteoblasts [103, 104]. It enhances VEGF-stimulated angiogenesis and attenuates effects of chronic hypoxia [105].

A number of in vivo animal models have all demonstrated that TP508 could have an upregulatory effect on bone healing (Table 2). Two animal studies, analysing the effect of TP508 loaded on PPF composite and microsphere scaffolds on segmental bone defects in rabbits, showed enhanced bone formation with a higher torsional stiffness of bone [99, 101]. TP508 injected into the fracture gap promotes fracture healing and increased blood vessel formation $[95,97,102]$. In animal models of distraction osteogenesis, injection of TP508 into the fracture gap resulted in enhanced bone formation and consolidation [94, 100]. In similar models, increased numbers of osteoblasts were apparent as well as the increased quality of bone $[96,98,100]$.

In the clinical setting, TP508 has failed to display the same beneficial effects as in animal studies. A doubleblinded, randomized, placebo controlled Phase III clinical trial has been conducted to analyse the effect of Chrysalin for the treatment of unstable displaced distal radial fractures [106]. The initial results demonstrated a statistically significant shorter time to the radiologic consolidation of the fractures but not differences in terms of the range of motion, grip strength and VAS or DASH scores [107]. Furthermore, the trial failed to show any statistically significant difference in the time of removal of the immobilization device, which was the primary end point of the study [108].

\section{Cell-binding peptides \\ PepGen P-15}

The $\mathrm{P}-15$ peptide is a highly conserved peptide that consists of 15 amino acids identical to the cell-binding region of collagen type I [234]. P-15 enhances cell attachment to bone substitutes and upregulates extracellular matrix (ECM) production [112]. At the same time, it promotes cell survival and can be absorbed into a calcium phosphate substrate [111]. When P-15 is added in scaffold material, it results in a significantly higher gene expression of alkaline phosphatase (ALP), BMP-2 and BMP-7 [235]. This upregulated gene expression could suggest that P-15 promotes osteoblastic activity in human osteoblast cells. Indeed, P-15 was found to stimulate the proliferation and differentiation rate as well as the growth factor production of osteoblasts in vitro [113, $137,189]$. On the contrary, Vordemvenne et al. [104] reported that P-15 alone is not capable of upregulating the proliferation and calcifying potential of human osteoblasts 
Table 1 In vivo animal studies presenting the effect of osteogenic growth peptide (OGP) on bone and bone healing

\begin{tabular}{|c|c|c|c|}
\hline Study/Year & Model & Mode of delivery & Results \\
\hline Sun et al., 1998 [89] & Tibial fracture in rabbits & IV administration & - OGP treatment accelerated fracture union \\
\hline Brager et al., 2000 [85] & Femoral fracture in rats & $\begin{array}{l}\text { Systematic administration } \\
\text { of OGP ( } 25 \mathrm{ng} / \text { day) }\end{array}$ & $\begin{array}{l}\text { - OGP enhances proliferation and differentiation of osteogenic } \\
\text { cells possibly through the upregulation of TGF-beta }\end{array}$ \\
\hline Gabet et al., 2004 [83] & Mid-femoral fracture in rats & $\begin{array}{l}\text { Systematic administration } \\
\text { of OGP }\end{array}$ & $\begin{array}{l}\text { - OGP administration resulted in enhanced bridging across } \\
\text { fracture gap, higher volume of callus and newly formed bone }\end{array}$ \\
\hline Shuqiang et al., 2008 [84] & $\begin{array}{l}\text { Radial } 1.5 \mathrm{~cm} \text { segmental } \\
\text { defect in rabbits }\end{array}$ & OGP incorporated in PLGA & $\begin{array}{l}\text { - The rate of bone formation and volume were statistically } \\
\text { significantly upregulated in experimental group }\end{array}$ \\
\hline Zhao et al., 2011 [88] & $\begin{array}{l}\text { Distraction osteogenesis } \\
\text { in rabbit tibia }\end{array}$ & $\begin{array}{l}\text { Systematic administration } \\
\text { of OGP }(200 \mathrm{ng} / \mathrm{kg} / \text { day })\end{array}$ & $\begin{array}{l}\text { - OGP treatments resulted in greater torsional stiffness, higher } \\
\text { chondrocyte numbers and amount of newly formed bone }\end{array}$ \\
\hline
\end{tabular}

in vitro. When combined with PDGF, a statistically significant increase in both proliferation and calcification was noted [104].

Preclinical results have shown that P-15-containing bone graft substitutes could facilitate bone healing and regeneration [118]. In bone defects, application of P-15containing bone substitutes increased the rate of bone growth compared to the defects left empty or filled with bone substitute alone [120, 121, 123, 124, 132, 138]. In critical sized segmental defect in a rat radius, application of inorganic bone matrix together with P-15 resulted in positive effect on bone healing, without any immunogenic features and disease transmission risk [133]. The use of the same graft material was found as successful as autogenous bone graft in producing lumbar spinal fusion in an ovine model [119]. However, some controversial data exist, with some authors reporting less favourable results with $\mathrm{P}$-15-containing graft substitutes $[125,126]$. In addition, application of the P-15containing graft substitutes was found to accelerate the process of early bone formation response but not the long-term effect [129, 131, 135].

The majority of clinical evidence derives from substitutes for the oral cavity $[109,110,114-117,122,127$, $128,130,134,136,139]$. Periodontal osseous defects in 25 patients treated with combination of anorganic bovine-derived hydroxyapatite matrix and P-15 showed favourable clinical results [109]. In the treatment of nonunions limited evidence exists [236]. Gomar et al. [236] treated 22 patients with non-uniting fractures with P-15 containing bone graft substitutes. They reported a $90 \%$ success rate and concluded that it could be an effective, safe and economical alternative to autologous bone grafting.

Table 2 In vivo animal studies presenting the effect of TP508 on bone and bone healing

\begin{tabular}{|c|c|c|c|}
\hline Study/Year & Model & Mode of delivery & Results \\
\hline Hedberg et al., 2004 [101] & $\begin{array}{l}\text { Segmental bone defect } \\
\text { in rabbits }\end{array}$ & $\begin{array}{l}\text { PPF composite scaffolds with } \\
200 \text { or } 100 \mu \mathrm{g} \text { TP508 }\end{array}$ & $\begin{array}{l}\text { - Enhance bone formation with } 200 \mu \mathrm{g} \text { TP508 possibly } \\
\text { due to the initial high burst of the molecule }\end{array}$ \\
\hline Sheller et al., 2004 [99] & $\begin{array}{l}\text { Segmental bone defect } \\
\text { in rabbits }\end{array}$ & $\begin{array}{l}\text { Microspheres with } 100 \mu \mathrm{g} \text { or } \\
200 \mu \mathrm{g} \text { TP508 }\end{array}$ & $\begin{array}{l}\text { - Enhanced healing of the defects with higher torsional } \\
\text { stiffness in the animals treated with TP508 }\end{array}$ \\
\hline Li et al., 2005 [100] & $\begin{array}{l}\text { Distraction osteogenesis } \\
\text { in rabbits }\end{array}$ & $\begin{array}{l}30 \mu \mathrm{g} \text { or } 300 \mu \mathrm{g} \text { into the } \\
\text { distraction gap }\end{array}$ & $\begin{array}{l}\text { - Enhanced bone formation and consolidation, the } 300 \mu \mathrm{g} \\
\text { treatment group had the most advanced results }\end{array}$ \\
\hline Wang et al., 2005 [102] & Femoral fracture in rats & $\begin{array}{l}1 \mu \mathrm{g} \text { or } 10 \mu \mathrm{g} \text { in the } \\
\text { fracture gap }\end{array}$ & $\begin{array}{l}\text { - TP508 found to promote fracture healing by inducing } \\
\text { the levels of growth factors, inflammatory mediators } \\
\text { and angiogenesis-related genes }\end{array}$ \\
\hline Amir et al., 2007 [98] & $\begin{array}{l}\text { Distraction osteogenesis } \\
\text { in rabbits }\end{array}$ & $\begin{array}{l}30 \text { or } 300 \mu \mathrm{g} \text { into the } \\
\text { distraction gap }\end{array}$ & $\begin{array}{l}\text { - Enhance bone regeneration with increased number } \\
\text { of osteoblasts }\end{array}$ \\
\hline Li et al., 2007 [97] & Rat femoral fracture model & $\begin{array}{l}1 \mu \mathrm{g}, 10 \mu \mathrm{g} \text { or } 100 \mu \mathrm{g} \text { in } \\
\text { the fracture gap }\end{array}$ & $\begin{array}{l}\text { - TP508 accelerated fracture healing by upregulating } \\
\text { the expression levels of molecules involved in cellular } \\
\text { proliferation, cellular growth and apoptosis }\end{array}$ \\
\hline Wang et al., 2008 [96] & $\begin{array}{l}\text { Distraction osteogenesis } \\
\text { in rabbits }\end{array}$ & $\begin{array}{l}\text { Slow releasing TP508 } \\
\text { preparation ( } 300 \mu \mathrm{g} \text { in } \\
\text { PPF/PLGA microparticles) }\end{array}$ & $\begin{array}{l}\text { - Enhanced bone consolidation process with better } \\
\text { quality bone }\end{array}$ \\
\hline Hanratty et al., 2009 [95] & $\begin{array}{l}\text { High energy femoral } \\
\text { fracture in mice }\end{array}$ & $\begin{array}{l}10 \mu \mathrm{g} \text { or } 100 \mu \mathrm{g} \text { at fracture } \\
\text { site, or } 100 \mu \mathrm{g} \text { at muscles } \\
\text { adjacent the fracture }\end{array}$ & $\begin{array}{l}\text { - } 100 \mu \mathrm{g} \text { in fracture gap significantly increased bone } \\
\text { formation and fracture stiffness } \\
\text { - Less scar tissue and increased blood vessel formation } \\
\text { was noted when TP508 was injected in the adjacent to } \\
\text { the fracture muscles }\end{array}$ \\
\hline Cakarer et al., 2010 [94] & $\begin{array}{l}\text { Distraction osteogenesis } \\
\text { in rats }\end{array}$ & $\begin{array}{l}10 \mu \mathrm{g} \text { and } 100 \mu \mathrm{g} \\
\text { percutaneously }\end{array}$ & $\begin{array}{l}\text { - Significant larger area of consolidation in the animal } \\
\text { receiving TP508; the higher dose was more effective }\end{array}$ \\
\hline
\end{tabular}




\section{RGD containing peptide}

Arginyl-glycyl-aspartic acid (RGD) sequence is found in several molecules and constitutes a system of cell surface signalling [237]. Evidence suggests that RGD enhances cell attachment and spreading of osteoblasts onto scaffolds and graft material [140, 141, 159, 188] whilst increasing cellular proliferation and the expression of ALP, Runx2, osteocalcin, osteopontin and bone sialoprotein [141, 142, 146, 190, 191]. Further, it promotes osteoblast differentiation and mineralization [143, 144, 146, 157, 158, 197].

Limited in vivo studies exist today analysing the effect of RGD on bone healing; however, several authors have investigated the effect of RGD peptides on implant surfaces. RGD coated implants were found to have an increased peri-implant bone formation and enhanced direct bone apposition even in areas of poor surrounding bone [148, $149,151,152,155,156]$. This significantly increased the bone-to-implant contact [149]. When RGD-coated intramedullary nails were inserted into the tibia of male adult Wistar rats, the outcome was increased new bone formation [148]. Finally, it should be mentioned that RGDcontaining scaffolds used to deliver growth factors, such as BMP-2 to promote bone regeneration in experimental fracture models, exist with favourable results [150]. In contrast to the abovementioned results, some fracture models have shown that RGD utilization could have detrimental effects. Hennessy et al. [153] showed that, when RGD was combined with adsorbed tibial proteins like fibronectin, vitronectin and fibrinogen, a markedly detrimental effect on mesenchymal stem cell (MSC) adhesion and survival was observed. No significant effects of an additional RGD coating on HA surfaces were detected in a rabbit model for cementless joint prostheses [154].

\section{Other ECM-derived peptides}

In addition to P-15 and RGD, other ECM-derived peptides are currently being developed for potential applications in amplifying the bone healing response. They represent signalling domains found along the ECM protein chains and are capable of interacting with receptors on the cellular membrane.

GFOGER (glycine-phenylalanine-hydroxyproline-glycineglutamate-arginine) is a collagen-mimetic peptide. It selectively promotes $\alpha_{2} \beta_{1}$ integrin binding, which is a crucial event for osteoblastic differentiation [162]. Implants coated with GFOGER were found to improve peri-implant bone regeneration and osseointegration [162, 164]. Results showed significantly accelerated and increased bone formation in non-healing femoral defects compared to uncoated scaffolds and empty defects. GFOGER could be utilized as a growth factor delivery vehicle, which can upregulate the fracture healing response [161].

The collagen-binding motif (CBM) is a cleavage product of osteopontin that can specifically bind to collagen
[180]. The CBM was found to promote migration and osteogenic differentiation via the $\mathrm{Ca}^{2+} / \mathrm{CaMKII/ERK/}$ AP-1 signalling pathway [181]. In a rabbit calvarial defect model, application of an injectable gel containing synthetic CBM peptide resulted in increased cell adhesion and growth of osteoblasts followed by increased osteoblastic differentiation and marked bone formation [180, 238].

DGEA (Asp-Gly-Glu-Ala) is a recognition motif used by type I collagen to bind to $\alpha_{2} \beta_{1}$ integrin [165]. This collagen peptide sequence has been shown to promote cell adhesion, spreading and osteogenic differentiation $[163,165,166]$. DGEA, engineered to express a heptaglutamate domain, was found to accumulate within bone tissue following intravenous injection [168], suggesting that such an approach could be used for drug to bone delivery. DGEA coupled with heptaglutamate-containing hydroxyapatite was found to enhance the adhesion and osteoblastic differentiation of MSCs as well as to increase new bone formation and bone-to-implant contact [167].

The SVVYGLR (Ser-Val-Val-Tyr-Gly-Leu-Arg) peptide sequence is found adjacent to the RGD sequence in osteopontin [239]. SVVYGLR peptide significantly enhanced the adhesion and proliferation of MSCs but also endothelial cell activity, resulting in an upregulation of neovascularization [169, 239, 240]. Experimental models of bone defects have shown that, when SVVYGLR was implanted together with a collagen sponge, an upregulation of osteogenesis and angiogenesis was observed [169, 239].

KRSR (lysine-arginine-serine-arginine) is a heparinbinding site found in fibronectin, vitronectin, bone sialoprotein, thrombospondin, and osteopontin [173]. KRSR increased osteoblast adhesion and osteogenic gene expression [171, 172, 177, 178]. Anodized nanotubular titanium coated with KRSR, RGDS (arginine-glycineaspartic acid-serine) and molecular plasma deposition increased osteoblast density compared with uncoated substrates [174]. Likewise, KRSR and RGD coated on titanium promoted the greatest osteoblast densities relative to untreated titanium [175]. On the contrary, less favourable results in terms of stimulation of cell adhesion and spreading were reported by other studies $[173,179]$.

FHRRIKA (Phe-His-Arg-Arg-Ile-Lys-Ala) is a cellbinding and putative heparin-binding domain of bone sialoprotein. FHRRIKA could have a favourable effect on osteoblast adhesion, spreading and mineralization [183]. Osteoblast outgrowths from rat calvarial bone chips covered a significantly larger area on FHRRIKA surface [176]. Rat calvarial osteoblasts seeded into a scaffold containing the RGD and FHRRIKA sequences were found to remain viable and have higher proliferation kinetics compared to the controls in which no peptides were added [184].

Fibronectin (FN)-derived peptides have also shown to facilitate osteoblast adhesion, spreading and mineralization 
[185]. A fibrin-binding synthetic oligopeptide derived from FN was found to enhance new bone formation in rabbit calvarial defect model [187]. In addition, the multifunctional FN III9-10/12-14 greatly enhanced the regenerative effects of BMP-2 and PDGF-BB in a rat critical-size bone defect model [186].

\section{NEMO-binding domain peptide (NBD)}

The inhibitor of nuclear factor kappa-B kinase (IKK) is a high molecular weight complex consisting of two catalytic subunits (IKK-1 and IKK-2) and a non-catalytic regulatory subunit NF-kB Essential Modulator (NEMO or IKK- $\gamma$ ) [194]. NEMO interacts with both IKK subunits at the interacting region to amino acids 737-742, called the NEMO-binding domain (NBD) [194]. NBD peptide has shown to promote osteoblast differentiation and inhibit bone resorption [192, 193]. A protective role to the bone by blocking osteoclastogenesis and bone erosion in inflammatory arthritis was also noted [195]. In vivo evidence is limited to a murine tooth extraction model treated with lipopolysaccharide injection where TNF-a retarded bone regeneration [196].

\section{Cell penetrating peptides}

Cell penetrating peptides (CPPs) are peptides that can transverse the cellular membrane and transport their 'cargo' into the cytoplasm [241]. Such cargos include proteins, siRNA, nanoparticles, oligonucleotides, and other peptides [242]. CPPs can derive from bacteria and viruses or synthesized in the laboratory [241, 242]. Jo et al. [199] demonstrated that the CPP-conjugated co-activator-associated arginine methyltransferase 1 (CARM1) protein can be delivered into human MSCs and change their global gene expression profile. Furthermore, upregulation of their differentiation capacity was noted [199]. In a rabbit calvarial defect model treated with CPP with a transcriptional factor fusion protein resulted in significantly increased bone formation [200]. Similarly, in a critical-size calvarial defect model, the inclusion of tetrameric CPPs in ex vivo transduction of recombinant adenovirus expressing BMP-2 into MSCs promoted highly mineralized bone formation [201].

\section{Self-assembly peptides}

Self-assembly peptides are another class of peptides, referred by some as 'molecular Lego', that are composed of alternating hydrophilic and hydrophobic amino acid residues [243]. These residues have the tendency to spontaneously adopt a $\beta$-sheet structure when exposed to monovalent cation solutions or placed under physiological conditions [203, 243]. The outcome of this process is the formation of self-assembled matrices with interwoven nanofibers.
RADA16-I (AcN-RADARADARADARADA-CONH2) is a synthetic commercially available peptide (PuraMatrix). MSCs exhibited higher levels of expression of ALP, osteocalcin and Runx2 genes in RADA16-I-containing demineralized bone matrix (DBM) compared to only DBM [203]. Cell adhesion, proliferation and differentiation of osteoblasts were found to be superior in the RADA16-Icontaining scaffold [204]. In vivo data derived from a critically-sized femur defect in goats showed that the volume of newly formed bone from marrow-enriched RADA16-I/DBM was significantly higher compared to marrow-enriched DBM alone [203]. Other authors reported favourable outcomes with the utilization of RADA16-I self-assembly peptide [206-212]. The addition of BMP-2 in a hydrogel RADA16-I-containing scaffold significantly enhanced bone regeneration on the bone augmentation model in an animal bone defect model [205].

Peptide amphiphiles are another class of self-assembly peptides that can support osteoprogenitor cells and guide their differentiation $[215,216]$. Mineralized matrices containing peptide amphiphiles were found to promote osteogenic differentiation of human MSCs [213]. The combination of peptide amphiphiles with MSCs and platelet-rich plasma was found to promote bone formation and enhance angiogenesis [214].

\section{Other peptides}

Numerous peptides have been isolated from the majority of the existing growth factors and bone-related proteins. Peptides derived from fibroblast growth factor were found to upregulate osteoblast differentiation [202, 244]. Similarly, peptides have been derived from molecules like BMPs, transforming growth factor- $\beta$, vascular endothelial growth factor, insulin derived growth factor, although their potential role in bone healing and regeneration remains obscure $[217-219,222]$. Other peptides found to promote bone healing include the RANKLbinding peptide, AC-100, mechano growth factor E, and B2A2-K-NS (B2A) [223].

\section{Discussion}

Bone tissue engineering is a growing biomedical field. All recent advances in the field of growth factors, scaffolds and osteoprogenitor cells have boosted the application and further expansion of tissue engineering technologies. As far as growth factors are concerned, several drawbacks prohibit their widespread use. Difficulties arising from potential immunogenicity, large molecular weight, need for carriers for their delivery and instability in vivo are well recognized [188]. Moreover, concerns regarding their sterilization and their theoretical involvement in carcinogenesis also exist [23, 188, 245-247]. The discovery that small protein segments (peptides) have the capacity to exert a similar effect 
could overcome some of the abovementioned problems. Not only do they have low immunogenicity but they can also be easily synthesised and handled [188].

Chrysalin and teriparatide are two commercially available drugs that have been investigated as potential candidates in the upregulation of bone healing response in humans [28]. Their background in terms of pre-clinical and experimental evidence has been excellent. In humans, teriparatide resulted in a shorter time to healing with a 'richer' callus formation when used for the treatment of distal radial fractures [28]. These results, however, are rather weak and, according to the authors, they should be interpreted with caution and warrant further validation with more studies. Similarly, the use of
Chrysalin for unstable displaced distal radial fractures demonstrated a shorter time to the radiologic consolidation of the fractures but no differences in terms of cast removal, range of motion, grip strength and VAS or DASH scores [107]. Therefore, one could hypothesise that the 'exceptional' results seen in the experimental animal models cannot be directly translated in clinical practice, at least as yet. It could be speculated that the differences in bone healing biology are responsible for these compelling results. In addition, differences in the study objectives in humans and animals are evident. The available in vitro and in vivo animal studies have limited their focus on the global osteogenic output. However, clinical studies are not limited to the radiologic appearance, but also several other

Table 3 Available clinical studies on the effect of peptides on bone healing

\begin{tabular}{|c|c|c|c|}
\hline Study, Year & Peptide used & Clinical application & Result \\
\hline Yukna et al., 1998 [115] & P-15 & $\begin{array}{l}\text { Periodontal osseous defects } \\
\text { in } 33 \text { patients }\end{array}$ & $\begin{array}{l}\text { P-15 combined with anorganic bone matrix (ABM) yields } \\
\text { better clinical results than freeze-dried bone allograft or } \\
\text { open flap debridement }\end{array}$ \\
\hline Yukna et al., 2000 [114] & P-15 & $\begin{array}{l}\text { Periodontal osseous defects } \\
\text { in } 33 \text { patients }\end{array}$ & $\begin{array}{l}\text { - P-15 combined with ABM yields better clinical results than } \\
\text { the ABM alone }\end{array}$ \\
\hline Yukna et al., 2002 [122] & $P-15$ & $\begin{array}{l}\text { Infra-bony periodontal defects } \\
\text { in } 25 \text { patients }\end{array}$ & $\begin{array}{l}\text { - Favourable } 3 \text {-year results with P-15 combined with ABM } \\
\text { suggest that it may have a beneficial effect long-term }\end{array}$ \\
\hline Yukna et al., 2002 [109] & $P-15$ & $\begin{array}{l}\text { Periodontal regeneration case } \\
\text { report }\end{array}$ & $\begin{array}{l}\text { - Uneventful results with no evidence of root resorption, } \\
\text { ankylosis or untoward inflammation }\end{array}$ \\
\hline Degidi et al., 2004 [128] & $P-15$ & $\begin{array}{l}\text { Maxillary sinus augmentation } \\
\text { in } 7 \text { patients }\end{array}$ & $\begin{array}{l}\text { - Bone-replacement materials, without the addition of autologous } \\
\text { bone, could be equally effective sinus augmentation }\end{array}$ \\
\hline Gelbart et al., 2005 [110] & $P-15$ & $\begin{array}{l}\text { Sinus floor augmentation in } \\
12 \text { patients }\end{array}$ & $\begin{array}{l}\text { - New trabecular bone is formed after grafting P-15 combined } \\
\text { with ABM in the sinus floor }\end{array}$ \\
\hline Philippart et al., 2005 [130] & $P-15$ & $\begin{array}{l}\text { Maxillary sinus floor grafting } \\
\text { performed on } 3 \text { patients }\end{array}$ & $\begin{array}{l}\text { - High degree of inorganic xenograft integration and natural } \\
\text { bone regeneration }\end{array}$ \\
\hline Gomar et al. 2007 [236] & $P-15$ & $\begin{array}{l}\text { Non-unions and delayed union } \\
\text { in } 22 \text { patients }\end{array}$ & $\begin{array}{l}\text { - Full consolidation was achieved in } 90 \% \text { of the cases } \\
\text { - Safe, economical and clinically useful alternative to autograft } \\
\text { in the repair of un-united fractures }\end{array}$ \\
\hline Kasaj et al., 2008 [127] & $P-15$ & $\begin{array}{l}\text { Infra-bony periodontal defects } \\
\text { in } 26 \text { patients }\end{array}$ & $\begin{array}{l}\text { - Significantly improved clinical outcomes compared to open } \\
\text { flap debridement }\end{array}$ \\
\hline Butz et al., 2011 [116] & $P-15$ & $\begin{array}{l}\text { Sinus floor augmentation in } \\
24 \text { patients }\end{array}$ & $\begin{array}{l}\text { - All implants placed in the augmented sites integrated and } \\
\text { were restored prosthetically }\end{array}$ \\
\hline Emam et al., 2011 [117] & $P-15$ & $\begin{array}{l}\text { Sinus floor augmentation in } \\
24 \text { patients }\end{array}$ & $\begin{array}{l}\text { - PepGen P-15 putty was found to be a promising osteoconductive } \\
\text { graft for sinus augmentation, supporting immediate placement } \\
\text { of implants }\end{array}$ \\
\hline Aspenberg et al., 2010 [33] & Teriparatide & $\begin{array}{l}\text { Distal radial fractures in } \\
27 \text { patients }\end{array}$ & $\begin{array}{l}\text { - The results must be interpreted with caution } \\
\text { - Radiographic quality at an early time point might be a sensitive } \\
\text { variable, perhaps better than time to cortical continuity } \\
\text { - Teriparatide appeared to improve early callus formation in distal } \\
\text { radial fractures }\end{array}$ \\
\hline Aspenberg et al., 2010 [28] & Teriparatide & $\begin{array}{l}\text { Distal radial fractures in } \\
102 \text { patients }\end{array}$ & $\begin{array}{l}\text { - Shortened time to healing for teriparatide group compared with } \\
\text { placebo } \\
\text { - These results should be interpreted with caution and warrant } \\
\text { further study }\end{array}$ \\
\hline Chintamaneni et al., 2010 [34] & Teriparatide & Sternal fracture non-union & - Consolidation of fracture \\
\hline Oteo-Alvaro et al., 2010 [36] & Teriparatide & $\begin{array}{l}\text { Humeral shaft non-union } \\
\text { case report }\end{array}$ & - Consolidation of fracture \\
\hline Chrysalin trial [106] & Chrysalin & $\begin{array}{l}\text { Distal radial fractures in } \\
274 \text { patients }\end{array}$ & $\begin{array}{l}\text { - Statistically significant shorter time to the radiologic consolidation } \\
\text { of the fractures but no differences in terms of the range of motion, } \\
\text { grip strength and VAS or DASH scores }\end{array}$ \\
\hline
\end{tabular}


parameters such as time for cast removal, range of motion, VAS or DASH scores, etc. It could be of speculation that a more radiologically rich callus formation is not necessarily associated with a better clinical outcome (Table 3). In addition, the potency of these peptides in humans and animals, as well as their stability and delivery challenges, are currently not fully understood.

PepGen P-15 is another commercially available peptide that has been investigated in periodontal osseous defect models with favourable results. The vast majority of the available evidence comes from small osseous defects seen in dental and maxillofacial surgery (Table 3). There is limited evidence for long bone bony defects or nonunions. In the largest case series, PepGen P-15 containing bone graft substitutes were used in 22 patients with non-uniting fractures [236]. According to the authors, PepGen appeared to offer a safe, economical and clinically useful alternative to autologous grafting. However, additional randomized clinical studies are needed to define its effectiveness in this setting. In a similar note, the effectiveness of PuraMatrix warrants further clinical investigation as, although commercially available, its potential effectiveness for bone healing and regeneration is only limited to in vitro or animal studies.

One avenue that warrants further investigation includes the combination of cell binding peptides with sub-functional doses of BMPs [197, 248]. As shown, for instance, by Visser et al. [248], when an absorbable collagen type I sponge functionalized with a synthetic collagentargeted RGD containing low doses of BMP-2, ectopic bone formation was observed in rats. These low BMP-2 levels would have no significant effect if applied on their own.

Further research in the nanoscale phenomena governing biological materials and the heterojunction between cells and substrate could allow osteoinductive implants coupled with osteoconductive properties. Small molecules such as peptides could have a role to play in supporting and guiding the overall osteogenic response in such scenarios. Overcoming the peptide stability issues against proteolysis, which result in a short duration of activity and low bioavailability, is also crucial. In this context, expansion of our methodology for peptide designs with further research on ways to improve the incorporation of non-natural amino acids, cyclization and stable peptide bond engineering are crucial. The development of improved peptide motifs that could increase the osteogenic response in a compromised bone healing environment rather than cause an upregulation of the osteoblastic output, should further be explored. Another area of interest is the utilization of a 'polytherapy', i.e. the combination of several peptides targeting either a specific cell line or a specific phase of bone healing. Such an approach would, for instance, employ an osteoinductive peptide coupled by a peptide promoting the osteogenic or chondrogenic response. Scaffold technologies enabling a timed controlled release of such molecules could provide the right signals at the exact phase of the bone healing pathway. Therefore, further persistence in the design of peptide-scale molecules capable of targeting the upregulation of osteogenesis or form functional, structurally complex and well-defined scaffolds will lead to future clinical treatment modalities ranging from tissue replacement to tissue regeneration.

\section{Conclusion}

A significant number of peptides have been developed and investigated as potential candidates for the upregulation of bone healing response. In vitro and experimental animal models have been favourable, however, limited clinical evidence exists. Maturation of our knowledge in this field will give rise to novel biologically-derived molecules for applications in the clinical setting in cases where bone healing and bone regeneration are needed.

\section{Acknowledgements}

No acknowledgement to be made. No benefits in any form have been received or will be received from a commercial party related directly or indirectly to the subject of this article. No funds were received in support of this study.

\section{Funding}

No funds were received in support to this study. No benefits in any form have been received or will be received from a commercial party related directly or indirectly to the subject of this article.

\section{Authors' contributions}

IP: Writing of the manuscript, study design, data collection and interpretation, preparation of revisions. MP: Data collection, assistance in study design and data interpretation. AL: Data collection, assistance in data interpretation. EJ: Generic input, study design. GMC: Contributed important intellectual content. PVG: Study senior author, study design, overview and final approval of the study. All authors read and approved the final manuscript.

\section{Competing interest}

The authors declare that they have no competing interests.

\section{Author details}

${ }^{1}$ Department of Trauma \& Orthopaedics, School of Medicine, University of Leeds, Leeds, UK. ${ }^{2}$ Unit of Musculoskeletal Disease, Leeds Institute of Rheumatic and Musculoskeletal Medicine, St. James University Hospital, University of Leeds, LS9 7TF Leeds, UK. ${ }^{3}$ Department of Trauma \& Orthopaedics, School of Medicine, ISTITUTO ORTOPEDICO GAETANO PINI, Milan, Italy. ${ }^{4} \mathrm{NIHR}$ Leeds Biomedical Research Unit, Chapel Allerton Hospital, LS7 4SA Leeds, West Yorkshire, Leeds, UK.

Published online: 11 July 2016

References

1. Hak DJ, Fitzpatrick D, Bishop JA, Marsh JL, Tilp S, Schnettler R, et al. Delayed union and nonunions: epidemiology, clinical issues, and financial aspects. Injury. 2014:45 Suppl 2:S3-7.

2. Hankenson KD, Zimmerman G, Marcucio R. Biological perspectives of delayed fracture healing. Injury. 2014;45 Suppl 2:S8-S15.

3. Giorgio Calori M, Capanna R, Colombo M, De Biase P, O'Sullivan C, Cartareggia $V$, et al. Cost effectiveness of tibial nonunion treatment: a comparison between rhBMP-7 and autologous bone graft in two Italian centres. Injury. 2013;44(12):1871-9. 
4. Panteli M, Pountos I, Jones E, Giannoudis PV. Biological and molecular profile of fracture non-union tissue: current insights. J Cell Mol Med. 2015; 19(4):685-713.

5. Giannoudis PV, Panteli M, Calori GM. Bone healing: the diamond concept. In: Bentley G, editor. European Instructional Lectures. Volume 14th ed. Berlin Heidelberg: Springer; 2014. p. 3-16.

6. Giannoudis PV, Calori GM, Begue T, Schmidmaier G. Bone regeneration strategies: current trends but what the future holds? Injury. 2013;44 Suppl 1:S1-2

7. Dahabreh Z, Panteli M, Pountos I, Howard M, Campbell P, Giannoudis PV. Ability of bone graft substitutes to support the osteoprogenitor cells: an in-vitro study. World J Stem Cells. 2014;6(4):497-504.

8. Zura R, Della Rocca GJ, Mehta S, Harrison A, Brodie C, Jones J, et al. Treatment of chronic ( $>1$ year) fracture nonunion: heal rate in a cohort of 767 patients treated with low-intensity pulsed ultrasound (LIPUS). Injury. 2015:46(10):2036-41.

9. Ashman O, Phillips AM. Treatment of non-unions with bone defects: which option and why? Injury. 2013:44 Suppl 1:\$43-45.

10. Goff T, Kanakaris NK, Giannoudis PV. Use of bone graft substitutes in the management of tibial plateau fractures. Injury. 2013:44 Suppl 1:S86-94.

11. Zimmermann G, Moghaddam A. Allograft bone matrix versus synthetic bone graft substitutes. Injury. 2011:42 Suppl 2:S16-21.

12. Calori GM, Colombo M, Mazza EL, Mazzola S, Malagoli E, Mineo GV. Incidence of donor site morbidity following harvesting from iliac crest or RIA graft. Injury. 2014;45 Suppl 6:S116-120.

13. Guimaraes JA, Duarte ME, Fernandes MB, Vianna VF, Rocha TH, Bonfim DC, et al. The effect of autologous concentrated bone-marrow grafting on the healing of femoral shaft non-unions after locked intramedullary nailing. Injury. 2014;45 Suppl 5:S7-S13.

14. Pountos I, Georgouli T, Kontakis G, Giannoudis PV. Efficacy of minimally invasive techniques for enhancement of fracture healing: evidence today. Int Orthop. 2010;34(1):3-12

15. Memeo A, Verdoni F, De Bartolomeo O, Albisetti W, Pedretti L. A new way to treat forearm post-traumatic non-union in young patients with intramedullary nailing and platelet-rich plasma. Injury. 2014;45(2):418-23.

16. Ong KL, Villarraga ML, Lau E, Carreon LY, Kurtz SM, Glassman SD. Off-label use of bone morphogenetic proteins in the United States using administrative data. Spine (Phila Pa 1976). 2010;35(19):1794-800.

17. Ronga M, Fagetti A, Canton G, Paiusco E, Surace MF, Cherubino P. Clinical applications of growth factors in bone injuries: experience with BMPs. Injury. 2013:44 Suppl 1:S34-39.

18. Schutzenberger S, Kaipel M, Schultz A, Nau T, Redl H, Hausner T. Non-union site debridement increased the efficacy of rhBMP-2 in a rodent model. Injury. 2014;45(8):1165-70.

19. Pountos I, Georgouli T, Henshaw K, Bird H, Giannoudis PV. Release of growth factors and the effect of age, sex, and severity of injury after long bone fracture. A preliminary report. Acta Orthop. 2013;84(1):65-70.

20. Pountos I, Georgouli T, Henshaw K, Bird H, Jones E, Giannoudis PV. The effect of bone morphogenetic protein-2, bone morphogenetic protein-7, parathyroid hormone, and platelet-derived growth factor on the proliferation and osteogenic differentiation of mesenchymal stem cells derived from osteoporotic bone. J Orthop Trauma. 2010;24(9):552-6.

21. Pountos I, Panteli M, Panagiotopoulos E, Jones E, Giannoudis PV. Can we enhance fracture vascularity: what is the evidence? Injury. 2014;45 Suppl 2 S49-57.

22. Roberto-Rodrigues M, Fernandes RM, Senos R, Scoralick AC, Bastos AL, Santos TM, et al. Novel rat model of nonunion fracture with vascular deficit. Injury. 2015;46(4):649-54.

23. Pountos I, Panteli M, Georgouli T, Giannoudis PV. Neoplasia following use of BMPS: is there an increased risk? Expert Opin Drug Saf. 2014;13(11):1525-34.

24. Massia SP, Hubbell JA. An RGD spacing of $440 \mathrm{~nm}$ is sufficient for integrin alpha $V$ beta 3-mediated fibroblast spreading and $140 \mathrm{~nm}$ for focal contact and stress fiber formation. J Cell Biol. 1991;114(5):1089-100.

25. Dignass AU, Sturm A. Peptide growth factors in the intestine. Eur J Gastroenterol Hepatol. 2001;13(7):763-70.

26. Moher D, Liberati A, Tetzlaff J, Altman DG, PRISMA Group. Preferred reporting items for systematic reviews and meta-analyses: the PRISMA statement. BMJ. 2009;339:b2535.

27. Alkhiary YM, Gerstenfeld LC, Krall E, Westmore M, Sato M, Mitlak BH, et al. Enhancement of experimental fracture-healing by systemic administration of recombinant human parathyroid hormone (PTH 1-34). J Bone Joint Surg Am. 2005;87(4):731-41.
28. Aspenberg P, Genant HK, Johansson T, Nino AJ, See K, Krohn K, et al. Teriparatide for acceleration of fracture repair in humans: a prospective, randomized, double-blind study of 102 postmenopausal women with distal radial fractures. J Bone Miner Res. 2010;25(2):404-14.

29. Jung RE, Hammerle $\mathrm{CH}$, Kokovic V, Weber FE. Bone regeneration using a synthetic matrix containing a parathyroid hormone peptide combined with a grafting material. Int J Oral Maxillofac Implants. 2007;22(2):258-66.

30. Komrakova M, Stuermer EK, Werner C, Wicke M, Kolios L, Sehmisch S, et al. Effect of human parathyroid hormone hPTH (1-34) applied at different regimes on fracture healing and muscle in ovariectomized and healthy rats. Bone. 2010;47(3):480-92.

31. Mognetti B, Marino S, Barberis A, Martin AS, Bala Y, Di Carlo F, et al. Experimental stimulation of bone healing with teriparatide: histomorphometric and microhardness analysis in a mouse model of closed fracture. Calcif Tissue Int. 2011:89(2):163-71.

32. Rowshan HH, Parham MA, Baur DA, McEntee RD, Cauley E, Carriere DT, et al. Effect of intermittent systemic administration of recombinant parathyroid hormone (1-34) on mandibular fracture healing in rats. J Oral Maxillofac Surg. 2010;68(2):260-7.

33. Aspenberg $P$, Johansson $T$. Teriparatide improves early callus formation in distal radial fractures. Acta Orthop. 2010:81(2):234-6.

34. Chintamaneni S, Finzel K, Gruber BL. Successful treatment of sternal fracture nonunion with teriparatide. Osteoporos Int. 2010;21(6):1059-63.

35. Gomberg SJ, Wustrack RL, Napoli N, Arnaud CD, Black DM. Teriparatide, vitamin D, and calcium healed bilateral subtrochanteric stress fractures in a postmenopausal woman with a 13-year history of continuous alendronate therapy. J Clin Endocrinol Metab. 2011;96(6):1627-32.

36. Oteo-Alvaro A, Moreno E. Atrophic humeral shaft nonunion treated with teriparatide (rh PTH 1-34): a case report. J Shoulder Elbow Surg. 2010;19(7): e22-28.

37. Paridis D, Karachalios T. Atrophic femoral bone nonunion treated with 1-84 PTH. J Musculoskelet Neuronal Interact. 2011;11(4):320-2. Quiz 323.

38. Rubery PT, Bukata SV. Teriparatide may accelerate healing in delayed unions of type III odontoid fractures: a report of 3 cases. J Spinal Disord Tech. 2010; 23(2): 151-5

39. Wu CC, Wei JC, Hsieh CP, Yu CT. Enhanced healing of sacral and pubic insufficiency fractures by teriparatide. J Rheumatol. 2012;39(6):1306-7.

40. Yu CT, Wu JK, Chang CC, Chen CL, Wei JC. Early callus formation in human hip fracture treated with internal fixation and teriparatide. J Rheumatol. 2008;35(10):2082-3.

41. Holm J, Eiken P, Hyldstrup L, Jensen JE. Atypical femoral fracture in an osteogenesis imperfecta patient successfully treated with teriparatide. Endocr Pract. 2014;20(10):e187-190.

42. Nozaka K, Shimada Y, Miyakoshi N, Yamada S, Hongo M, Kasukawa Y, et al. Combined effect of teriparatide and low-intensity pulsed ultrasound for nonunion: a case report. BMC Res Notes. 2014;7:317

43. Tachiiri H, Okuda Y, Yamasaki T, Kusakabe T. Weekly teriparatide administration for the treatment of delayed union: a report of two cases. Arch Osteoporos. 2014;9:179.

44. Fukuda F, Kurinomaru N, Hijioka A. Weekly teriparatide for delayed unions of atypical subtrochanteric femur fractures. Biol Ther. 2014;4(1-2):73-9.

45. Ochi K, Ikari K, Naomi A, Momohara S. Administration of teriparatide treatment for a challenging case of nonunion of periprosthetic fracture after total knee arthroplasty. Arch Osteoporos. 2013;8:159.

46. Bashutski JD, Eber RM, Kinney JS, Benavides E, Maitra S, Braun TM, et al. Teriparatide and osseous regeneration in the oral cavity. N Engl J Med. 2010;363(25):2396-405.

47. Pietrogrande $L$, Raimondo E. Teriparatide in the treatment of non-unions: scientific and clinical evidences. Injury. 2013;44 Suppl 1:S54-57.

48. Morgan EF, Mason ZD, Bishop G, Davis AD, Wigner NA, Gerstenfeld LC, et al. Combined effects of recombinant human BMP-7 (rhBMP-7) and parathyroid hormone (1-34) in metaphyseal bone healing. Bone. 2008;43(6):1031-8.

49. Manabe T, Mori S, Mashiba T, Kaji Y, Iwata K, Komatsubara S, et al. Human parathyroid hormone (1-34) accelerates natural fracture healing process in the femoral osteotomy model of cynomolgus monkeys. Bone. 2007:40(6):1475-82.

50. Komatsubara S, Mori S, Mashiba T, Nonaka K, Seki A, Akiyama T, et al. Human parathyroid hormone (1-34) accelerates the fracture healing process of woven to lamellar bone replacement and new cortical shell formation in rat femora. Bone. 2005;36(4):678-87.

51. Whitfield JF, Morley P, Willick GE. Parathyroid hormone, its fragments and their analogs for the treatment of osteoporosis. Treat Endocrinol. 2002;1(3):175-90. 
52. Peggion E, Mammi S, Schievano E, Silvestri L, Schiebler L, Bisello A, et al. Structure-function studies of analogues of parathyroid hormone (PTH)-1-34 containing beta-amino acid residues in positions 11-13. Biochemistry. 2002; 41(25):8162-75.

53. Karaplis AC, Deckelbaum RA. Role of PTHrP and PTH-1 receptor in endochondral bone development. Front Biosci. 1998;3:d795-803.

54. Vickery BH, Avnur Z, Cheng Y, Chiou SS, Leaffer D, Caulfield JP, et al. RS-66271, a C-terminally substituted analog of human parathyroid hormone-related protein (1-34), increases trabecular and cortical bone in ovariectomized, osteopenic rats. J Bone Miner Res. 1996;11(12):1943-51.

55. Bostrom MP, Asnis P, Toledano T, Hill EL, Avnur Z, Vickery B. The enhancement of fracture healing in the rat using a PTHrP analog. J Orthop Trauma. 1999:13(4):294-5.

56. Bostrom MP, Gamradt SC, Asnis P, Vickery BH, Hill E, Avnur Z, et al. Parathyroid hormone-related protein analog RS-66271 is an effective therapy for impaired bone healing in rabbits on corticosteroid therapy. Bone. 2000:26(5):437-42

57. de Castro LF, Lozano D, Portal-Nunez S, Maycas M, De la Fuente M, Caeiro $\mathrm{JR}$, et al. Comparison of the skeletal effects induced by daily administration of PTHrP (1-36) and PTHrP (107-139) to ovariectomized mice. J Cell Physiol. 2012;227(4):1752-60

58. Trejo CG, Lozano D, Manzano M, Doadrio JC, Salinas AJ, Dapia S, et al. The osteoinductive properties of mesoporous silicate coated with osteostatin in a rabbit femur cavity defect model. Biomaterials. 2010;31(33):8564-73.

59. Kim YJ, Kim HJ, Im Gl. PTHrP promotes chondrogenesis and suppresses hypertrophy from both bone marrow-derived and adipose tissue-derived MSCs. Biochem Biophys Res Commun. 2008:373(1):104-8.

60. Amling M, Neff L, Tanaka S, Inoue D, Kuida K, Weir E, et al. Bcl-2 lies downstream of parathyroid hormone-related peptide in a signaling pathway that regulates chondrocyte maturation during skeletal development. J Cell Biol. 1997;136(1):205-13.

61. Du P, Ye Y, Seitz PK, Bi LG, Li H, Wang C, et al. Endogenous parathyroid hormone-related peptide enhances proliferation and inhibits differentiation in the osteoblast-like cell line ROS 17/2.8. Bone. 2000;26(5):429-36.

62. Guo J, Liu M, Yang D, Bouxsein ML, Thomas CC, Schipani E, et al. Phospholipase C signaling via the parathyroid hormone (PTH)/PTH-related peptide receptor is essential for normal bone responses to PTH. Endocrinology. 2010;151(8):3502-13.

63. Mrak E, Guidobono F, Moro G, Fraschini G, Rubinacci A, Villa I. Calcitonin gene-related peptide (CGRP) inhibits apoptosis in human osteoblasts by beta-catenin stabilization. J Cell Physiol. 2010;225(3):701-8.

64. Villa I, Melzi R, Pagani F, Ravasi F, Rubinacci A, Guidobono F. Effects of calcitonin gene-related peptide and amylin on human osteoblast-like cells proliferation. Eur J Pharmacol. 2000;409(3):273-8.

65. Ballica R, Valentijn K, Khachatryan A, Guerder S, Kapadia S, Gundberg C, et al. Targeted expression of calcitonin gene-related peptide to osteoblasts increases bone density in mice. J Bone Miner Res. 1999;14(7):1067-74.

66. Kruger L, Silverman JD, Mantyh PW, Sternini C, Brecha NC. Peripheral patterns of calcitonin-gene-related peptide general somatic sensory innervation: cutaneous and deep terminations. J Comp Neurol. 1989;280(2):291-302.

67. Drissi H, Hott M, Marie PJ, Lasmoles F. Expression of the CT/CGRP gene and its regulation by dibutyryl cyclic adenosine monophosphate in human osteoblastic cells. J Bone Miner Res. 1997;12(11):1805-14.

68. Drissi H, Lieberherr M, Hott M, Marie PJ, Lasmoles F. Calcitonin gene-related peptide (CGRP) increases intracellular free $\mathrm{Ca} 2+$ concentrations but not cyclic AMP formation in CGRP receptor-positive osteosarcoma cells (OHS-4). Cytokine. 1999;11(3):200-7.

69. Schinke T, Liese S, Priemel M, Haberland M, Schilling AF, Catala-Lehnen P, et al. Decreased bone formation and osteopenia in mice lacking alphacalcitonin gene-related peptide. J Bone Miner Res. 2004;19(12):2049-56.

70. Song Y, Bi L, Zhang Z, Huang Z, Hou W, Lu X, et al. Increased levels of calcitonin gene-related peptide in serum accelerate fracture healing following traumatic brain injury. Mol Med Rep. 2012;5(2):432-8.

71. Li J, Kreicbergs A, Bergstrom J, Stark A, Ahmed M. Site-specific CGRP innervation coincides with bone formation during fracture healing and modeling: a study in rat angulated tibia. J Orthop Res. 2007;25(9):1204-12.

72. Onuoha GN. Circulating sensory peptide levels within $24 \mathrm{~h}$ of human bone fracture. Peptides. 2001;22(7):1107-10.

73. Madsen JE, Hukkanen M, Aune AK, Basran I, Moller JF, Polak JM, et al. Fracture healing and callus innervation after peripheral nerve resection in rats. Clin Orthop Relat Res. 1998;351:230-40
74. Sample SJ, Hao Z, Wilson AP, Muir P. Role of calcitonin gene-related peptide in bone repair after cyclic fatigue loading. PLoS One. 2011;6(6):e20386.

75. Wang L, Shi X, Zhao R, Halloran BP, Clark DJ, Jacobs CR, et al. Calcitoningene-related peptide stimulates stromal cell osteogenic differentiation and inhibits RANKL induced NF-kappaB activation, osteoclastogenesis and bone resorption. Bone. 2010;46(5):1369-79.

76. Calland JW, Harris SE, Carnes Jr DL. Human pulp cells respond to calcitonin gene-related peptide in vitro. J Endod. 1997;23(8):485-9.

77. Vignery A, McCarthy TL. The neuropeptide calcitonin gene-related peptide stimulates insulin-like growth factor I production by primary fetal rat osteoblasts. Bone. 1996;18(4):331-5.

78. Millet I, Vignery A. The neuropeptide calcitonin gene-related peptide inhibits TNF-alpha but poorly induces IL-6 production by fetal rat osteoblasts. Cytokine. 1997;9(12):999-1007.

79. Xu G, Jiang D. The role and mechanism of exogenous calcitonin generelated peptide on mesenchymal stem cell proliferation and osteogenetic formation. Cell Biochem Biophys. 2014;69(2):369-78.

80. Zheng S, Li W, Xu M, Bai X, Zhou Z, Han J, et al. Calcitonin gene-related peptide promotes angiogenesis via AMP-activated protein kinase. Am J Physiol Cell Physiol. 2010;299(6):C1485-92.

81. Bab I, Gazit D, Chorev M, Muhlrad A, Shteyer A, Greenberg Z, et al. Histone H4-related osteogenic growth peptide (OGP): a novel circulating stimulator of osteoblastic activity. EMBO J. 1992;11(5):1867-73.

82. Greenberg Z, Gavish H, Muhlrad A, Chorev M, Shteyer A, Attar-Namdar M, et al. Isolation of osteogenic growth peptide from osteoblastic MC3T3 E1 cell cultures and demonstration of osteogenic growth peptide binding proteins. J Cell Biochem. 1997;65(3):359-67.

83. Gabet Y, Muller R, Regev E, Sela J, Shteyer A, Salisbury K, et al. Osteogenic growth peptide modulates fracture callus structural and mechanical properties. Bone. 2004;35(1):65-73.

84. Shuqiang M, Kunzheng W, Xiaoqiang D, Wei W, Mingyu Z, Daocheng W. Osteogenic growth peptide incorporated into PLGA scaffolds accelerates healing of segmental long bone defects in rabbits. J Plast Reconstr Aesthet Surg. 2008;61(12):1558-60.

85. Brager MA, Patterson MJ, Connolly JF, Nevo Z. Osteogenic growth peptide normally stimulated by blood loss and marrow ablation has local and systemic effects on fracture healing in rats. J Orthop Res. 2000;18(1):133-9.

86. Fei Q, Guo C, Xu X, Gao J, Zhang J, Chen T, et al. Osteogenic growth peptide enhances the proliferation of bone marrow mesenchymal stem cells from osteoprotegerin-deficient mice by CDK2/cyclin A. Acta Biochim Biophys Sin Shanghai. 2010;42(11):801-6.

87. Spreafico A, Frediani B, Capperucci C, Leonini A, Gambera D, Ferrata P, et al. Osteogenic growth peptide effects on primary human osteoblast cultures: potential relevance for the treatment of glucocorticoid-induced osteoporosis. J Cell Biochem. 2006:98(4):1007-20.

88. Zhao ZY, Shao L, Zhao HM, Zhong ZH, Liu JY, Hao CG. Osteogenic growth peptide accelerates bone healing during distraction osteogenesis in rabbit tibia. J Int Med Res. 2011;39(2):456-63.

89. Sun $Y Q$, Ashhurst DE. Osteogenic growth peptide enhances the rate of fracture healing in rabbits. Cell Biol Int. 1998;22(4):313-9.

90. Chen ZX, Chang M, Peng YL, Zhao L, Zhan YR, Wang LJ, et al. Osteogenic growth peptide C-terminal pentapeptide [OGP(10-14)] acts on rat bone marrow mesenchymal stem cells to promote differentiation to osteoblasts and to inhibit differentiation to adipocytes. Regul Pept. 2007;142(1-2):16-23.

91. Smith E, Meyerrose TE, Kohler T, Namdar-Attar M, Bab N, Lahat O, et al. Leaky ribosomal scanning in mammalian genomes: significance of histone H4 alternative translation in vivo. Nucleic Acids Res. 2005;33(4):1298-308.

92. An G, Xue Z, Zhang B, Deng QK, Wang YS, Lv SC. Expressing osteogenic growth peptide in the rabbit bone mesenchymal stem cells increased alkaline phosphatase activity and enhanced the collagen accumulation. Eur Rev Med Pharmacol Sci. 2014;18(11):1618-24.

93. Chen Z, Wang X, Shao Y, Shi D, Chen T, Cui D, et al. Synthetic osteogenic growth peptide promotes differentiation of human bone marrow mesenchymal stem cells to osteoblasts via RhoA/ROCK pathway. Mol Cell Biochem. 2011;358(1-2):221-7.

94. Cakarer S, Olgac V, Aksakalli N, Tang A, Keskin C. Acceleration of consolidation period by thrombin peptide 508 in tibial distraction osteogenesis in rats. Br J Oral Maxillofac Surg. 2010:48(8):633-6.

95. Hanratty BM, Ryaby JT, Pan XH, Li G. Thrombin related peptide TP508 promoted fracture repair in a mouse high energy fracture model. J Orthop Surg Res. 2009;4:1 
96. Wang Y, Wan C, Szoke G, Ryaby JT, Li G. Local injection of thrombin-related peptide (TP508) in PPF/PLGA microparticles-enhanced bone formation during distraction osteogenesis. J Orthop Res. 2008;26(4):539-46.

97. Li X, Wang H, Touma E, Qi Y, Rousseau E, Quigg RJ, et al. TP508 accelerates fracture repair by promoting cell growth over cell death. Biochem Biophys Res Commun. 2007;364(1):187-93.

98. Amir LR, Li G, Schoenmaker T, Everts $V$, Bronckers AL. Effect of thrombin peptide 508 (TP508) on bone healing during distraction osteogenesis in rabbit tibia. Cell Tissue Res. 2007;330(1):35-44.

99. Sheller MR, Crowther RS, Kinney JH, Yang J, Di Jorio S, Breunig T, et al. Repair of rabbit segmental defects with the thrombin peptide, TP508. J Orthop Res. 2004;22(5):1094-9.

100. Li G, Ryaby JT, Carney DH, Wang H. Bone formation is enhanced by thrombin-related peptide TP508 during distraction osteogenesis. J Orthop Res. 2005;23(1):196-202.

101. Hedberg EL, Kroese-Deutman HC, Shih CK, Crowther RS, Carney DH, Mikos $A G$, et al. Effect of varied release kinetics of the osteogenic thrombin peptide TP508 from biodegradable, polymeric scaffolds on bone formation in vivo. J Biomed Mater Res A. 2005;72(4):343-53.

102. Wang H, Li X, Tomin E, Doty SB, Lane JM, Carney DH, et al. Thrombin peptide (TP508) promotes fracture repair by up-regulating inflammatory mediators, early growth factors, and increasing angiogenesis. J Orthop Res. 2005;23(3):671-9.

103. Li G, Cui Y, Mcllmurray L, Allen WE, Wang H. rhBMP-2, rhVEGF(165), rhPTN and thrombin-related peptide, TP508 induce chemotaxis of human osteoblasts and microvascular endothelial cells. J Orthop Res. 2005;23(3):680-5.

104. Vordemvenne T, Paletta JR, Hartensuer R, Pap T, Raschke MJ, Ochman S. Cooperative effects in differentiation and proliferation between PDGF-BB and matrix derived synthetic peptides in human osteoblasts. BMC Musculoskelet Disord. 2011;12:263.

105. Olszewska-Pazdrak B, Carney DH. Systemic administration of thrombin peptide TP508 enhances VEGF-stimulated angiogenesis and attenuates effects of chronic hypoxia. J Vasc Res. 2013;50(3):186-96.

106. A Study to Evaluate the Safety and Effectiveness of Different Doses of Chrysalin in Adults Who Have a Broken Wrist. http://clinicaltrials.gov/ct2/ show/results/NCT00131482. Accessed 12 Oct 2015.

107. Ryaby JT, Sheller MR, Levine BP, Bramlet DG, Ladd AL, Carney DH. Thrombin peptide TP508 stimulates cellular events leading to angiogenesis, revascularization, and repair of dermal and musculoskeletal tissues. J Bone Joint Surg Am. 2006;88 Suppl 3:132-9.

108. Dent-Acosta RE, Storm N, Steiner RS, San Martin J. The tactics of modernday regulatory trials. J Bone Joint Surg Am. 2012;94 Suppl 1:39-44.

109. Yukna RA, Krauser JT, Callan DP, Evans GH, Cruz R, Martin M. Thirty-six month follow-up of 25 patients treated with combination anorganic bovine-derived hydroxyapatite matrix (ABM)/cell-binding peptide (P-15) bone replacement grafts in human infrabony defects. I. Clinical findings. J Periodontol. 2002;73(1):123-8.

110. Gelbart M, Friedman R, Burlui V, Rohrer M, Atkinson B. Maxillary sinus augmentation using a peptide-modified graft material in three mixtures: a prospective human case series of histologic and histomorphometric results. Implant Dent. 2005;14(2):185-93.

111. Hanks T, Atkinson BL. Comparison of cell viability on anorganic bone matrix with or without P-15 cell binding peptide. Biomaterials. 2004; 25(19):4831-6.

112. Yang $X B$, Bhatnagar RS, Li S, Oreffo RO. Biomimetic collagen scaffolds for human bone cell growth and differentiation. Tissue Eng. 2004;10(7-8):1148-59.

113. Kubler A, Neugebauer J, Oh JH, Scheer M, Zoller JE. Growth and proliferation of human osteoblasts on different bone graft substitutes: an in vitro study. Implant Dent. 2004;13(2):171-9.

114. Yukna RA, Krauser JT, Callan DP, Evans GH, Cruz R, Martin M. Multi-center clinical comparison of combination anorganic bovine-derived hydroxyapatite matrix (ABM)/cell binding peptide (P-15) and ABM in human periodontal osseous defects. 6-month results. J Periodontol. 2000;71(11):1671-9.

115. Yukna RA, Callan DP, Krauser JT, Evans GH, Aichelmann-Reidy ME, Moore K, et al. Multi-center clinical evaluation of combination anorganic bovinederived hydroxyapatite matrix (ABM)/cell binding peptide (P-15) as a bone replacement graft material in human periodontal osseous defects. 6-month results. J Periodontol. 1998;69(6):655-63.

116. Butz F, Bachle M, Ofer M, Marquardt K, Kohal RJ. Sinus augmentation with bovine hydroxyapatite/synthetic peptide in a sodium hyaluronate carrier (PepGen P-15 Putty): a clinical investigation of different healing times. Int J Oral Maxillofac Implants. 2011;26(6):1317-23.
117. Emam H, Beheiri G, Elsalanty M, Sharawy M. Microcomputed tomographic and histologic analysis of anorganic bone matrix coupled with cell-binding peptide suspended in sodium hyaluronate carrier after sinus augmentation: a clinical study. Int J Oral Maxillofac Implants. 2011;26(3):561-70.

118. Matos S, Guerra F, Krauser JT, Figueiredo H, Marcelino JP, Sanz M. Evaluation of an anorganic bovine-derived mineral with P-15 hydrogel bone graft: preliminary study in a rabbit cranial bone model. Clin Oral Implants Res. 2012;23(6):698-705.

119. Sherman BP, Lindley EM, Turner AS, Seim 3rd HB, Benedict J, Burger EL, et al. Evaluation of ABM/P-15 versus autogenous bone in an ovine lumbar interbody fusion model. Eur Spine J. 2010;19(12):2156-63.

120. Lindley EM, Guerra FA, Krauser JT, Matos SM, Burger EL, Patel W. Small peptide (P-15) bone substitute efficacy in a rabbit cancellous bone model. J Biomed Mater Res B Appl Biomater. 2010;94(2):463-8.

121. El-Madany I, Emam H, Sharawy M. Comparison of cellular response to anorganic bone matrix/cell binding peptide and allogenic cranial bone after sinus augmentation in rhesus monkeys. J Oral Implantol. 2011;37(2):233-45.

122. Yukna R, Salinas TJ, Carr RF. Periodontal regeneration following use of ABM/ P-1 5: a case report. Int J Periodontics Restorative Dent. 2002;22(2):146-55.

123. Suaid FA, Macedo GO, Novaes AB, Borges GJ, Souza SL, Taba M, et al. The bone formation capabilities of the anorganic bone matrix-synthetic cellbinding peptide 15 grafts in an animal periodontal model: a histologic and histomorphometric study in dogs. J Periodontol. 2010;81(4):594-603.

124. Artzi Z, Kozlovsky A, Nemcovsky CE, Moses O, Tal H, Rohrer MD, et al. Histomorphometric evaluation of natural mineral combined with a synthetic cell-binding peptide (P-15) in critical-size defects in the rat calvaria. Int J Oral Maxillofac Implants. 2008;23(6):1063-70.

125. Mardas N, Stavropoulos A, Karring T. Calvarial bone regeneration by a combination of natural anorganic bovine-derived hydroxyapatite matrix coupled with a synthetic cell-binding peptide (PepGen): an experimental study in rats. Clin Oral Implants Res. 2008;19(10):1010-5.

126. Sarahrudi K, Mousavi M, Grossschmidt K, Sela N, Konig F, Vecsei V, et al. Combination of anorganic bovine-derived hydroxyapatite with binding peptide does not enhance bone healing in a critical-size defect in a rabbit model. J Orthop Res. 2008;26(6):759-63.

127. Kasaj A, Rohrig B, Reichert C, Willershausen B. Clinical evaluation of anorganic bovine-derived hydroxyapatite matrix/cell-binding peptide (P-15) in the treatment of human infrabony defects. Clin Oral Investig. 2008;12(3):241-7.

128. Degidi M, Piattelli M, Scarano A, lezzi G, Piattelli A. Maxillary sinus augmentation with a synthetic cell-binding peptide: histological and histomorphometrical results in humans. J Oral Implantol. 2004;30(6):376-83.

129. Thorwarth M, Schultze-Mosgau S, Wehrhan F, Srour S, Wiltfang J, Neukam FW, et al. Enhanced bone regeneration with a synthetic cell-binding peptide-in vivo results. Biochem Biophys Res Commun. 2005;329(2):789-95.

130. Philippart $P$, Daubie V, Pochet R. Sinus grafting using recombinant human tissue factor, platelet-rich plasma gel, autologous bone, and anorganic bovine bone mineral xenograft: histologic analysis and case reports. Int J Oral Maxillofac Implants. 2005;20(2):274-81.

131. Thorwarth M, Schultze-Mosgau S, Wehrhan F, Kessler P, Srour S, Wiltfang J et al. Bioactivation of an anorganic bone matrix by $\mathrm{P}-15$ peptide for the promotion of early bone formation. Biomaterials. 2005;26(28):5648-57.

132. Vastardis S, Yukna RA, Mayer ET, Atkinson BL. Periodontal regeneration with peptide-enhanced anorganic bone matrix in particulate and putty form in dogs. J Periodontol. 2005;76(10):1690-6.

133. Cakmak G, Bolukbasi S, Simsek A, Erdem O, Yilmaz G, Senkoylu A. Effect of synthetic cell-binding peptide on the healing of cortical segmental bone defects. Saudi Med J. 2006;27(6):777-80.

134. Barros RR, Novaes Jr AB, Roriz VM, Oliveira RR, Grisi MF, Souza SL, et al. Anorganic bovine matrix/p-15 "flow" in the treatment of periodontal defects: case series with 12 months of follow-up. J Periodontol. 2006;77(7):1280-7.

135. Artzi Z, Weinreb M, Tal H, Nemcovsky CE, Rohrer MD, Prasad HS, et al. Experimental intrabony and periodontal defects treated with natural mineral combined with a synthetic cell-binding Peptide in the canine: morphometric evaluations. J Periodontol. 2006;77(10):1658-64.

136. Bhongade ML, Tiwari IR. A comparative evaluation of the effectiveness of an anorganic bone matrix/cell binding peptide with an open flap debridement in human infrabony defects: a clinical and radiographic study. J Contemp Dent Pract. 2007:8(6):25-34.

137. Trasatti C, Spears R, Gutmann JL, Opperman LA. Increased Tgf-beta1 production by rat osteoblasts in the presence of PepGen P-15 in vitro. J Endod. 2004;30(4):213-7. 
138. Scarano A, lezzi G, Petrone G, Orsini G, Degidi M, Strocchi R, et al. Cortical bone regeneration with a synthetic cell-binding peptide: a histologic and histomorphometric pilot study. Implant Dent. 2003;12(4):318-24.

139. Barboza EP, de Souza RO, Caula AL, Neto LG, Caula Fde O, Duarte ME. Bone regeneration of localized chronic alveolar defects utilizing cell binding peptide associated with anorganic bovine-derived bone mineral: a clinical and histological study. J Periodontol. 2002;73(10):1153-9.

140. Durrieu MC, Pallu S, Guillemot F, Bareille R, Amedee J, Baquey CH, et al. Grafting RGD containing peptides onto hydroxyapatite to promote osteoblastic cells adhesion. J Mater Sci Mater Med. 2004;15(7):779-86.

141. Huang H, Zhao Y, Liu Z, Zhang Y, Zhang H, Fu T, et al. Enhanced osteoblast functions on RGD immobilized surface. J Oral Implantol. 2003;29(2):73-9.

142. El-Ghannam AR, Ducheyne P, Risbud M, Adams CS, Shapiro IM, Castner D, et al. Model surfaces engineered with nanoscale roughness and RGD tripeptides promote osteoblast activity. J Biomed Mater Res A. 2004;68(4):615-27.

143. Cavalcanti-Adam EA, Shapiro IM, Composto RJ, Macarak EJ, Adams CS. RGD peptides immobilized on a mechanically deformable surface promote osteoblast differentiation. J Bone Miner Res. 2002;17(12):2130-40.

144. Dee KC, Rueger DC, Andersen TT, Bizios R. Conditions which promote mineralization at the bone-implant interface: a model in vitro study. Biomaterials. 1996;17(2):209-15.

145. Hofmann S, Hilbe M, Fajardo RJ, Hagenmuller H, Nuss K, Arras M, et al. Remodeling of tissue-engineered bone structures in vivo. Eur J Pharm Biopharm. 2013;85(1):119-29.

146. Thein-Han W, Liu J, Xu HH. Calcium phosphate cement with biofunctional agents and stem cell seeding for dental and craniofacial bone repair. Dent Mater. 2012;28(10):1059-70.

147. Hayashibara T, Hiraga T, Yi B, Nomizu M, Kumagai Y, Nishimura R, et al. A synthetic peptide fragment of human MEPE stimulates new bone formation in vitro and in vivo. J Bone Miner Res. 2004;19(3):455-62.

148. Rammelt S, Illert T, Bierbaum S, Scharnweber D, Zwipp H, Schneiders W. Coating of titanium implants with collagen, RGD peptide and chondroitin sulfate. Biomaterials. 2006;27(32):5561-71.

149. Park JW, Kurashima K, Tustusmi Y, An CH, Suh JY, Doi H, et al. Bone healing of commercial oral implants with RGD immobilization through electrodeposited poly(ethylene glycol) in rabbit cancellous bone. Acta Biomater. 2011;7(8):3222-9.

150. Priddy LB, Chaudhuri O, Stevens HY, Krishnan L, Uhrig BA, Willett NJ, et al. Oxidized alginate hydrogels for bone morphogenetic protein-2 delivery in long bone defects. Acta Biomater. 2014;10(10):4390-9.

151. Ferris DM, Moodie GD, Dimond PM, Gioranni CW, Ehrlich MG, Valentini RF. RGD-coated titanium implants stimulate increased bone formation in vivo. Biomaterials. 1999;20(23-24):2323-31.

152. Schneiders W, Reinstorf A, Pompe W, Grass R, Biewener A, Holch M, et al. Effect of modification of hydroxyapatite/collagen composites with sodium citrate, phosphoserine, phosphoserine/RGD-peptide and calcium carbonate on bone remodelling. Bone. 2007:40(4):1048-59.

153. Hennessy KM, Clem WC, Phipps MC, Sawyer AA, Shaikh FM, Bellis SL. The effect of RGD peptides on osseointegration of hydroxyapatite biomaterials. Biomaterials. 2008;29(21):3075-83.

154. Bitschnau A, Alt V, Bohner F, Heerich KE, Margesin E, Hartmann S, et al. Comparison of new bone formation, implant integration, and biocompatibility between RGD-hydroxyapatite and pure hydroxyapatite coating for cementless joint prostheses-an experimental study in rabbits. J Biomed Mater Res B Appl Biomater. 2009;88(1):66-74.

155. Elmengaard B, Bechtold JE, Soballe K. In vivo effects of RGD-coated titanium implants inserted in two bone-gap models. J Biomed Mater Res A. 2005; 75(2):249-55

156. Elmengaard B, Bechtold JE, Soballe K. In vivo study of the effect of RGD treatment on bone ongrowth on press-fit titanium alloy implants. Biomaterials. 2005;26(17):3521-6.

157. Rezania A, Thomas CH, Branger AB, Waters CM, Healy KE. The detachment strength and morphology of bone cells contacting materials modified with a peptide sequence found within bone sialoprotein. J Biomed Mater Res. 1997:37(1):9-19.

158. Shin H, Temenoff JS, Bowden GC, Zygourakis K, Farach-Carson MC, Yaszemski MJ, et al. Osteogenic differentiation of rat bone marrow stroma cells cultured on Arg-Gly-Asp modified hydrogels without dexamethasone and beta-glycerol phosphate. Biomaterials. 2005;26(17):3645-54.

159. Gilbert M, Shaw WJ, Long JR, Nelson K, Drobny GP, Giachelli CM, et al. Chimeric peptides of statherin and osteopontin that bind hydroxyapatite and mediate cell adhesion. J Biol Chem. 2000;275(21):16213-8.
160. Wojtowicz AM, Shekaran A, Oest ME, Dupont KM, Templeman KL, Hutmacher DW, et al. Coating of biomaterial scaffolds with the collagen-mimetic peptide GFOGER for bone defect repair. Biomaterials. 2010;31(9):2574-82.

161. Shekaran A, Garcia JR, Clark AY, Kavanaugh TE, Lin AS, Guldberg RE, et al. Bone regeneration using an alpha 2 beta 1 integrin-specific hydrogel as a BMP-2 delivery vehicle. Biomaterials. 2014;35(21):5453-61.

162. Reyes CD, Petrie TA, Burns KL, Schwartz Z, Garcia AJ. Biomolecular surface coating to enhance orthopaedic tissue healing and integration. Biomaterials. 2007;28(21):3228-35

163. Hennessy KM, Pollot BE, Clem WC, Phipps MC, Sawyer AA, Culpepper BK, et al. The effect of collagen I mimetic peptides on mesenchymal stem cell adhesion and differentiation, and on bone formation at hydroxyapatite surfaces. Biomaterials. 2009:30(10):1898-909.

164. Reyes CD, Garcia AJ. Alpha2beta1 integrin-specific collagen-mimetic surfaces supporting osteoblastic differentiation. J Biomed Mater Res A. 2004; 69(4):591-600

165. Ceylan H, Kocabey S, Unal Gulsuner H, Balcik OS, Guler MO, Tekinay AB. Bone-like mineral nucleating peptide nanofibers induce differentiation of human mesenchymal stem cells into mature osteoblasts. Biomacromolecules. 2014;15(7):2407-18.

166. Yoo SY, Kobayashi M, Lee PP, Lee SW. Early osteogenic differentiation of mouse preosteoblasts induced by collagen-derived DGEA-peptide on nanofibrous phage tissue matrices. Biomacromolecules. 2011;12(4):987-96.

167. Culpepper BK, Phipps MC, Bonvallet PP, Bellis SL. Enhancement of peptide coupling to hydroxyapatite and implant osseointegration through collagen mimetic peptide modified with a polyglutamate domain. Biomaterials. 2010; 31(36):9586-94.

168. Culpepper BK, Bonvallet PP, Reddy MS, Ponnazhagan S, Bellis SL. Polyglutamate directed coupling of bioactive peptides for the delivery of osteoinductive signals on allograft bone. Biomaterials. 2013;34(5):1506-13.

169. Egusa H, Kaneda Y, Akashi Y, Hamada Y, Matsumoto T, Saeki M, et al. Enhanced bone regeneration via multimodal actions of synthetic peptide SWYGLR on osteoprogenitors and osteoclasts. Biomaterials. 2009;30(27):4676-86.

170. Hamada Y, Egusa H, Kaneda Y, Hirata I, Kawaguchi N, Hirao T, et al. Synthetic osteopontin-derived peptide SWYGLR can induce neovascularization in artificial bone marrow scaffold biomaterials. Dent Mater J. 2007;26(4):487-92

171. Palchesko RN, Romeo JD, McGowan KA, Gawalt ES. Increased osteoblast adhesion on physically optimized KRSR modified calcium aluminate. J Biomed Mater Res A. 2012;100(5):1229-38.

172. Sun S, Yu W, Zhang Y, Zhang F. Increased preosteoblast adhesion and osteogenic gene expression on $\mathrm{TiO} 2$ nanotubes modified with KRSR. J Mater Sci Mater Med. 2013;24(4):1079-91.

173. Dee KC, Andersen TT, Bizios R. Design and function of novel osteoblastadhesive peptides for chemical modification of biomaterials. J Biomed Mater Res. 1998;40(3):371-7.

174. Balasundaram G, Shimpi TM, Sanow WR, Storey DM, Kitchell BS, Webster TJ. Molecular plasma deposited peptides on anodized nanotubular titanium: an osteoblast density study. J Biomed Mater Res A. 2011;98(2):192-200.

175. Zhang L, Hemraz UD, Fenniri $H$, Webster TJ. Tuning cell adhesion on titanium with osteogenic rosette nanotubes. J Biomed Mater Res A. 2010;95(2):550-63.

176. Schuler M, Hamilton DW, Kunzler TP, Sprecher CM, de Wild M, Brunette DM, et al. Comparison of the response of cultured osteoblasts and osteoblasts outgrown from rat calvarial bone chips to nonfouling KRSR and FHRRIKApeptide modified rough titanium surfaces. J Biomed Mater Res B Appl Biomater. 2009;91(2):517-27.

177. Nelson M, Balasundaram G, Webster TJ. Increased osteoblast adhesion on nanoparticulate crystalline hydroxyapatite functionalized with KRSR. Int J Nanomedicine. 2006;1(3):339-49.

178. Balasundaram G, Webster TJ. Increased osteoblast adhesion on nanograined Ti modified with KRSR. J Biomed Mater Res A. 2007:80(3):602-11.

179. Sawyer AA, Hennessy KM, Bellis SL. The effect of adsorbed serum proteins, RGD and proteoglycan-binding peptides on the adhesion of mesenchymal stem cells to hydroxyapatite. Biomaterials. 2007;28(3):383-92.

180. Lee JY, Choo JE, Park HJ, Park JB, Lee SC, Jo I, et al. Injectable gel with synthetic collagen-binding peptide for enhanced osteogenesis in vitro and in vivo. Biochem Biophys Res Commun. 2007;357(1):68-74.

181. Shin MK, Kim MK, Bae YS, Jo I, Lee SJ, Chung CP, et al. A novel collagenbinding peptide promotes osteogenic differentiation via Ca2+/calmodulindependent protein kinase II/ERKAP-1 signaling pathway in human bone marrow-derived mesenchymal stem cells. Cell Signal. 2008;20(4):613-24. 
182. Au A, Boehm CA, Mayes AM, Muschler GF, Griffith LG. Formation of osteogenic colonies on well-defined adhesion peptides by freshly isolated human marrow cells. Biomaterials. 2007;28(10):1847-61.

183. Rezania A, Healy KE. Biomimetic peptide surfaces that regulate adhesion, spreading, cytoskeletal organization, and mineralization of the matrix deposited by osteoblast-like cells. Biotechnol Prog. 1999;15(1):19-32.

184. Stile RA, Healy KE. Thermo-responsive peptide-modified hydrogels for tissue regeneration. Biomacromolecules. 2001;2(1):185-94.

185. Kim YJ, Park YJ, Lee YM, Rhyu IC, Ku Y. The biological effects of fibrinbinding synthetic oligopeptides derived from fibronectin on osteoblast-like cells. J Periodontal Implant Sci. 2012;42(4):113-8.

186. Martino MM, Tortelli F, Mochizuki M, Traub S, Ben-David D, Kuhn GA, et al. Engineering the growth factor microenvironment with fibronectin domains to promote wound and bone tissue healing. Sci Transl Med. 2011;3(100):100ra189.

187. Lee JA, Ku Y, Rhyu IC, Chung CP, Park YJ. Effects of fibrin-binding oligopeptide on osteopromotion in rabbit calvarial defects. J Periodontal Implant Sci. 2010;40(5):211-9.

188. Kantlehner M, Schaffner P, Finsinger D, Meyer J, Jonczyk A, Diefenbach B, et al. Surface coating with cyclic RGD peptides stimulates osteoblast adhesion and proliferation as well as bone formation. Chembiochem. 2000;1(2):107-14.

189. Liu Q, Limthongkul W, Sidhu G, Zhang J, Vaccaro A, Shenck R, et al. Covalent attachment of P15 peptide to titanium surfaces enhances cell attachment, spreading, and osteogenic gene expression. J Orthop Res. 2012; 30(10):1626-33.

190. Mota A, Sahebghadam Lotfi A, Barzin J, Hatam M, Adibi B, Khalaj Z, et al. Human bone marrow mesenchymal stem cell behaviors on PCL/gelatin nanofibrous scaffolds modified with a collagen IV-derived RGD-containing peptide. Cell J. 2014;16(1):1-10.

191. Chang JC, Hsu SH, Chen DC. The promotion of chondrogenesis in adiposederived adult stem cells by an RGD-chimeric protein in 3D alginate culture. Biomaterials. 2009;30(31):6265-75

192. Li W, Yu B, Li M, Sun D, Hu Y, Zhao M, et al. NEMO-binding domain peptide promotes osteoblast differentiation impaired by tumor necrosis factor alpha. Biochem Biophys Res Commun. 2010;391(2):1228-33.

193. Jimi E, Aoki K, Saito H, D’Acquisto F, May MJ, Nakamura I, et al. Selective inhibition of NF-kappa B blocks osteoclastogenesis and prevents inflammatory bone destruction in vivo. Nat Med. 2004;10(6):617-24.

194. Strnad J, McDonnell PA, Riexinger DJ, Mapelli C, Cheng L, Gray H, et al. NEMO binding domain of IKK-2 encompasses amino acids 735-745. J Mol Recognit. 2006;19(3):227-33.

195. Dai S, Hirayama T, Abbas S, Abu-Amer Y. The IkappaB kinase (IKK) inhibitor, NEMO-binding domain peptide, blocks osteoclastogenesis and bone erosion in inflammatory arthritis. J Biol Chem. 2004;279(36):37219-22.

196. Tomomatsu N, Aoki K, Alles N, Soysa NS, Hussain A, Nakachi H, et al. LPSinduced inhibition of osteogenesis is TNF-alpha dependent in a murine tooth extraction model. J Bone Miner Res. 2009:24(10):1770-81.

197. Martino MM, Briquez PS, Guc E, Tortelli F, Kilarski WW, Metzger S, et al. Growth factors engineered for super-affinity to the extracellular matrix enhance tissue healing. Science. 2014:343(6173):885-8.

198. Fukushima N, Hiraoka K, Shirachi I, Kojima M, Nagata K. Isolation and characterization of a novel peptide, osteoblast activating peptide (OBAP), associated with osteoblast differentiation and bone formation. Biochem Biophys Res Commun. 2010;400(1):157-63.

199. Jo J, Song H, Park SG, Lee SH, Ko JJ, Park JH, et al. Regulation of differentiation potential of human mesenchymal stem cells by intracytoplasmic delivery of coactivator-associated arginine methyltransferase 1 protein using cellpenetrating peptide. Stem Cells. 2012;30(8):1703-13.

200. Suh JS, Lee JY, Choi YJ, You HK, Hong SD, Chung CP, et al. Intracellular delivery of cell-penetrating peptide-transcriptional factor fusion protein and its role in selective osteogenesis. Int J Nanomedicine. 2014;9:1153-66.

201. Park SH, Doh J, Park SI, Lim JY, Kim SM, Youn Jl, et al. Branched oligomerization of cell-permeable peptides markedly enhances the transduction efficiency of adenovirus into mesenchymal stem cells. Gene Ther. 2010;17(8):1052-61.

202. Lee JY, Choo JE, Choi YS, Lee KY, Min DS, Pi SH, et al. Characterization of the surface immobilized synthetic heparin binding domain derived from human fibroblast growth factor-2 and its effect on osteoblast differentiation. J Biomed Mater Res A. 2007;83(4):970-9.

203. Li Z, Hou T, Luo F, Chang Z, Wu X, Xing J, et al. Bone marrow enriched graft, modified by self-assembly peptide, repairs critically-sized femur defects in goats. Int Orthop. 2014;38(11):2391-8.
204. Hou T, Li Z, Luo F, Xie Z, Wu X, Xing J, et al. A composite demineralized bone matrix-self assembling peptide scaffold for enhancing cell and growth factor activity in bone marrow. Biomaterials. 2014;35(22):5689-99.

205. Ikeno M, Hibi H, Kinoshita K, Hattori $H$, Ueda M. Effects of self-assembling peptide hydrogel scaffold on bone regeneration with recombinant human bone morphogenetic protein-2. Int J Oral Maxillofac Implants. 2013;28(5): e283-289.

206. Nakahara H, Misawa H, Yoshida A, Hayashi T, Tanaka M, Furumatsu T, et al. Bone repair using a hybrid scaffold of self-assembling peptide PuraMatrix and polyetheretherketone cage in rats. Cell Transplant. 2010;19(6):791-7.

207. Ozeki M, Kuroda S, Kon K, Kasugai S. Differentiation of bone marrow stromal cells into osteoblasts in a self-assembling peptide hydrogel: in vitro and in vivo studies. J Biomater Appl. 2011;25(7):663-84.

208. Yoshimi R, Yamada Y, Ito K, Nakamura S, Abe A, Nagasaka T, et al. Selfassembling peptide nanofiber scaffolds, platelet-rich plasma, and mesenchymal stem cells for injectable bone regeneration with tissue engineering. J Craniofac Surg. 2009;20(5):1523-30.

209. Misawa H, Kobayashi N, Soto-Gutierrez A, Chen Y, Yoshida A, Rivas-Carrillo $\mathrm{JD}$, et al. PuraMatrix facilitates bone regeneration in bone defects of calvaria in mice. Cell Transplant. 2006;15(10):903-10.

210. Horii A, Wang X, Gelain F, Zhang S. Biological designer self-assembling peptide nanofiber scaffolds significantly enhance osteoblast proliferation, differentiation and 3-D migration. PLoS One. 2007;2(2):e190.

211. Gelain F, Bottai D, Vescovi A, Zhang S. Designer self-assembling peptide nanofiber scaffolds for adult mouse neural stem cell 3-dimensional cultures. PLoS One. 2006;1:e119.

212. Garreta E, Gasset D, Semino C, Borros S. Fabrication of a three-dimensional nanostructured biomaterial for tissue engineering of bone. Biomol Eng. 2007:24(1):75-80.

213. Sargeant TD, Aparicio C, Goldberger JE, Cui H, Stupp SI. Mineralization of peptide amphiphile nanofibers and its effect on the differentiation of human mesenchymal stem cells. Acta Biomater. 2012:8(7):2456-65.

214. Murphy MB, Blashki D, Buchanan RM, Fan D, De Rosa E, Shah RN, et al. Multi-composite bioactive osteogenic sponges featuring mesenchymal stem cells, platelet-rich plasma, nanoporous silicon enclosures, and Peptide amphiphiles for rapid bone regeneration. J Funct Biomater. 2011;2(2):39-66.

215. Anderson JM, Vines JB, Patterson JL, Chen H, Javed A, Jun HW. Osteogenic differentiation of human mesenchymal stem cells synergistically enhanced by biomimetic peptide amphiphiles combined with conditioned medium. Acta Biomater. 2011;7(2):675-82.

216. Lee JY, Choo JE, Choi YS, Suh JS, Lee SJ, Chung CP, et al. Osteoblastic differentiation of human bone marrow stromal cells in self-assembled BMP2 receptor-binding peptide-amphiphiles. Biomaterials. 2009;30(21):3532-41.

217. Verheyen A, Peeraer E, Lambrechts D, Poesen K, Carmeliet P, Shibuya M, et al. Therapeutic potential of VEGF and VEGF-derived peptide in peripheral neuropathies. Neuroscience. 2013;244:77-89.

218. Guan J. Insulin-like growth factor-1 and its derivatives: potential pharmaceutical application for ischemic brain injury. Recent Pat CNS Drug Discov. 2008;3(2):112-27.

219. Saito A, Suzuki Y, Kitamura M, Ogata S, Yoshihara Y, Masuda S, et al. Repair of 20-mm long rabbit radial bone defects using BMP-derived peptide combined with an alpha-tricalcium phosphate scaffold. J Biomed Mater Res A. 2006;77(4):700-6.

220. Deng M, Zhang B, Wang K, Liu F, Xiao H, Zhao J, et al. Mechano growth factor $\mathrm{E}$ peptide promotes osteoblasts proliferation and bone-defect healing in rabbits. Int Orthop. 2011;35(7):1099-106.

221. Smucker JD, Bobst JA, Petersen EB, Nepola JV, Fredericks DC. B2A peptide on ceramic granules enhance posterolateral spinal fusion in rabbits compared with autograft. Spine (Phila Pa 1976). 2008;33(12):1324-9.

222. Ezquerro IJ, Lasarte JJ, Dotor J, Castilla-Cortazar I, Bustos M, Penuelas I, et al. A synthetic peptide from transforming growth factor beta type III receptor inhibits liver fibrogenesis in rats with carbon tetrachloride liver injury. Cytokine. 2003;22(1-2):12-20.

223. Furuya $Y$, Inagaki $A$, Khan $M$, Mori $K$, Penninger JM, Nakamura $M$, et al. Stimulation of bone formation in cortical bone of mice treated with a receptor activator of nuclear factor-kappaB ligand (RANKL)-binding peptide that possesses osteoclastogenesis inhibitory activity. J Biol Chem. 2013; 288(8):5562-71.

224. Fujita T, Fukase M, Baba H, Yamaguchi T, Takata S, Fujimi T, et al. New actions of parathyroid hormone through its degradation. J Endocrinol Invest. 1992;15(9 Suppl 6):121-7. 
225. Tamai K, Takamatsu K, Kazuki K. Successful treatment of nonunion with teriparatide after failed ankle arthrodesis for Charcot arthropathy. Osteoporos Int. 2013;24(10):2729-32.

226. Martin TJ, Moseley JM, Gillespie MT. Parathyroid hormone-related protein: biochemistry and molecular biology. Crit Rev Biochem Mol Biol. 1991;26(3-4): 377-95.

227. Zhao Q, Brauer PR, Xiao L, McGuire MH, Yee JA. Expression of parathyroid hormone-related peptide (PthrP) and its receptor (PTH1R) during the histogenesis of cartilage and bone in the chicken mandibular process. J Anat. 2002;201(2):137-51.

228. Cupp ME, Nayak SK, Adem AS, Thomsen WJ. Parathyroid hormone (PTH) and PTH-related peptide domains contributing to activation of different PTH receptormediated signaling pathways. J Pharmacol Exp Ther. 2013;345(3):404-18.

229. Wang YH, Qiu Y, Han XD, Xiong J, Chen YX, Shi HF, et al. Haploinsufficiency of endogenous parathyroid hormone-related peptide impairs bone fracture healing. Clin Exp Pharmacol Physiol. 2013;40(11):715-23.

230. Amara SG, Jonas V, Rosenfeld MG, Ong ES, Evans RM. Alternative RNA processing in calcitonin gene expression generates mRNAs encoding different polypeptide products. Nature. 1982;298(5871):240-4.

231. Tian G, Zhang G, Tan YH. Calcitonin gene-related peptide stimulates BMP-2 expression and the differentiation of human osteoblast-like cells in vitro. Acta Pharmacol Sin. 2013;34(11):1467-74.

232. Bab I, Gavish H, Namdar-Attar M, Muhlrad A, Greenberg Z, Chen Y, et al. Isolation of mitogenically active C-terminal truncated pentapeptide of osteogenic growth peptide from human plasma and culture medium of murine osteoblastic cells. J Pept Res. 1999;54(5):408-14.

233. Gabarin N, Gavish H, Muhlrad A, Chen YC, Namdar-Attar M, Nissenson RA, et al. Mitogenic G(i) protein-MAP kinase signaling cascade in MC3T3-E1 osteogenic cells: activation by C-terminal pentapeptide of osteogenic growth peptide [OGP(10-14)] and attenuation of activation by cAMP. J Cell Biochem. 2001;81(4):594-603.

234. Bhatnagar RS, Qian JJ, Wedrychowska A, Sadeghi M, Wu YM, Smith N Design of biomimetic habitats for tissue engineering with P-15, a synthetic peptide analogue of collagen. Tissue Eng. 1999;5(1):53-65.

235. Nguyen H, Qian JJ, Bhatnagar RS, Li S. Enhanced cell attachment and osteoblastic activity by $\mathrm{P}-15$ peptide-coated matrix in hydrogels. Biochem Biophys Res Commun. 2003;311(1):179-86.

236. Gomar F, Orozco R, Villar JL, Arrizabalaga F. P-15 small peptide bone graft substitute in the treatment of non-unions and delayed union. A pilot clinical trial. Int Orthop. 2007;31(1):93-9.

237. Ruoslahti E, Pierschbacher MD. Arg-Gly-Asp: a versatile cell recognition signal. Cell. 1986;44(4):517-8.

238. Lee JY, Choo JE, Choi YS, Park JB, Min DS, Lee SJ, et al. Assembly of collagen-binding peptide with collagen as a bioactive scaffold for osteogenesis in vitro and in vivo. Biomaterials. 2007;28(29):4257-67.

239. Hamada Y, Yuki K, Okazaki M, Fujitani W, Matsumoto T, Hashida MK, et al. Osteopontin-derived peptide SWYGLR induces angiogenesis in vivo. Dent Mater J. 2004;23(4):650-5.

240. Park KM, Lee Y, Son JY, Bae JW, Park KD. In situ SWYGLR peptide conjugation into injectable gelatin-poly(ethylene glycol)-tyramine hydroge via enzyme-mediated reaction for enhancement of endothelial cell activity and neo-vascularization. Bioconjug Chem. 2012;23(10):2042-50.

241. Karagiannis ED, Urbanska AM, Sahay G, Pelet JM, Jhunjhunwala S, Langer $R$, et al. Rational design of a biomimetic cell penetrating peptide library. ACS Nano. 2013;7(10):8616-26.

242. Jo J, Hong S, Choi WY, Lee DR. Cell-penetrating peptide (CPP)-conjugated proteins is an efficient tool for manipulation of human mesenchymal stromal cells. Sci Rep. 2014;4:4378.

243. Zhang S. Emerging biological materials through molecular self-assembly. Biotechnol Adv. 2002;20(5-6):321-39.

244. Lee JY, Choo JE, Choi YS, Shim IK, Lee SJ, Seol YJ, et al. Effect of immobilized cell-binding peptides on chitosan membranes for osteoblastic differentiation of mesenchymal stem cells. Biotechnol Appl Biochem. 2009; 52(Pt 1):69-77.

245. Mesfin A, Buchowski JM, Zebala LP, Bakhsh WR, Aronson AB, Fogelson JL, et al. High-dose rhBMP-2 for adults: major and minor complications: a study of 502 spine cases. J Bone Joint Surg Am. 2013;95(17):1546-53.

246. Latzman JM, Kong L, Liu C, Samadani U. Administration of human recombinant bone morphogenetic protein-2 for spine fusion may be associated with transient postoperative renal insufficiency. Spine (Phila Pa 1976). 2010;35(7):E231-237.
247. Simmonds MC, Brown JV, Heirs MK, Higgins JP, Mannion RJ, Rodgers MA, et al. Safety and effectiveness of recombinant human bone morphogenetic protein-2 for spinal fusion: a meta-analysis of individual-participant data. Ann Intern Med. 2013;158(12):877-89.

248. Visser R, Arrabal PM, Santos-Ruiz L, Fernandez-Barranco R, Becerra J, Cifuentes M. A collagen-targeted biomimetic RGD peptide to promote osteogenesis. Tissue Eng Part A. 2014;20(1-2):34-44.

\section{Submit your next manuscript to BioMed Central and we will help you at every step:}

- We accept pre-submission inquiries

- Our selector tool helps you to find the most relevant journal

- We provide round the clock customer support

- Convenient online submission

- Thorough peer review

- Inclusion in PubMed and all major indexing services

- Maximum visibility for your research

Submit your manuscript at www.biomedcentral.com/submit
) Biomed Central 